Linköping University Medical Dissertations No. 1766

\title{
Exercise training and testing in patients with heart failure
}

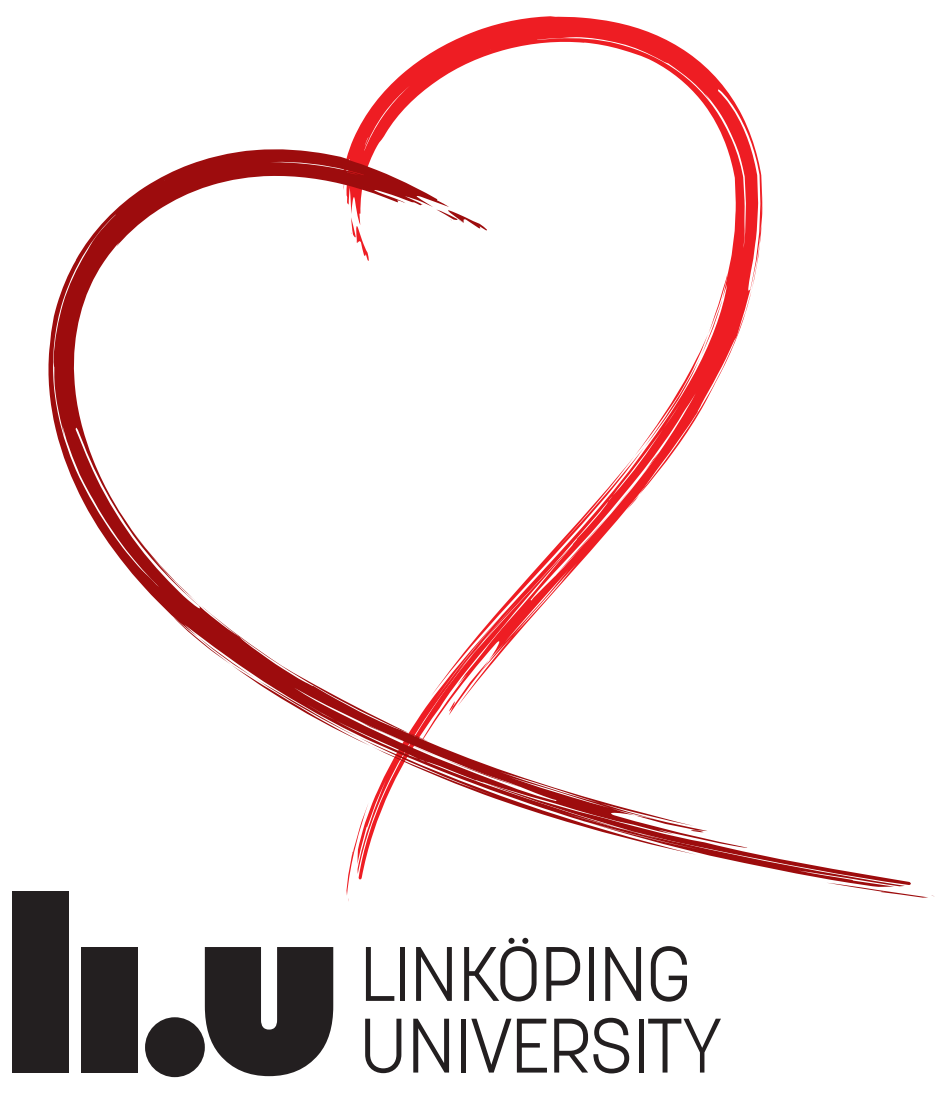

Charlotta Lans 

Linköping University Medical Dissertations No. 1766

\title{
Exercise training and testing in patients with heart failure
}

\author{
Charlotta Lans
}

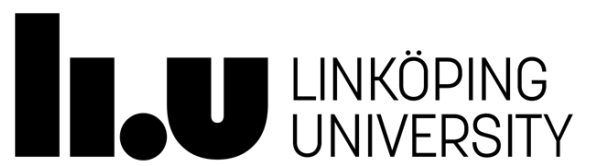

Department of Health, Medicine and Caring Sciences Linköping University, Sweden Linköping 2021 
(oc) EY-NG This work is licensed under a Creative Commons AttributionNonCommercial 4.0 International License.

https://creativecommons.org/licenses/by-nc/4.0/

(C) Charlotta Lans, 2021

Cover/picture/Illustration/Design: Charlotta Lans

Published article has been reprinted with the permission of the copyright holder.

Printed in Sweden by LiU-Tryck, Linköping, Sweden, 2021

ISBN 978-91-7929-742-8

ISSN $0345-0082$ 
To Janne, my husband and Johan, my deceased big brother, with love

"Lack of activity destroys the good condition of every human being, while movement and methodical physical exercise save it and preserve it" Plato 428-348 BC, Greek philosopher 



\section{CONTENTS}

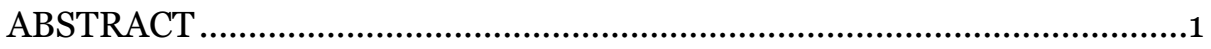

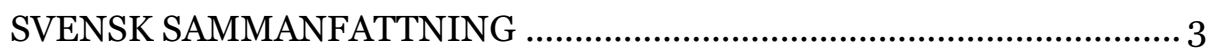

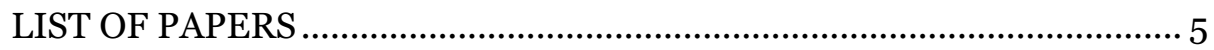

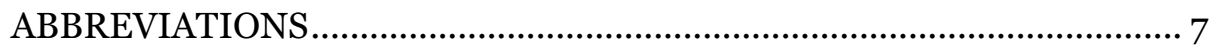

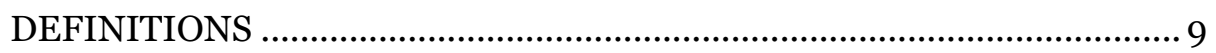

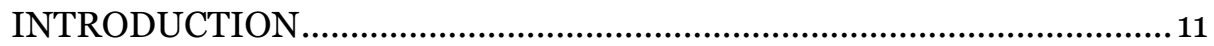

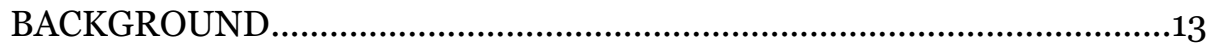

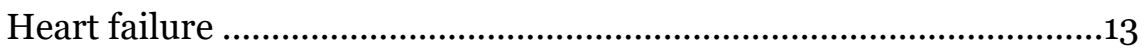

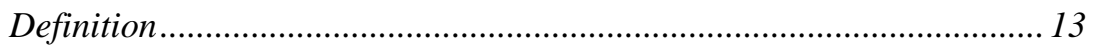

Pathophysiology ............................................................................. 13

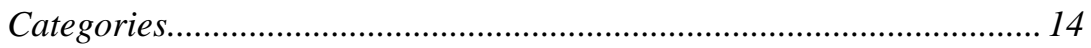

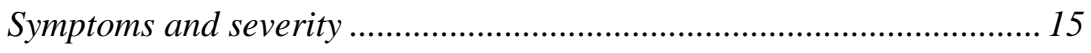

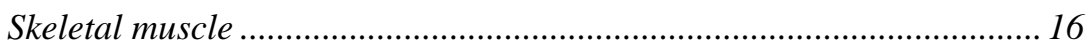

Exercise intolerance and capacity ..................................................... 17

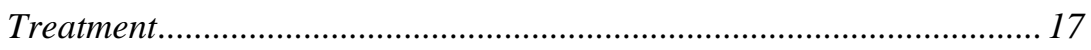

Physical activity and exercise................................................................ 18

Recommendations of physical activity and exercise ............................... 18

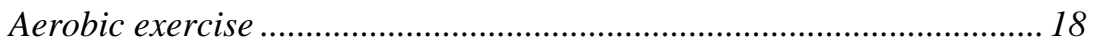

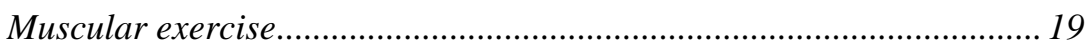

Exercise training in patients with heart failure ...................................... 19

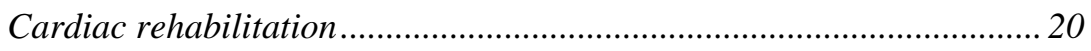

Physiotherapy management exercise based cardiac rehabilitation........ 21

Health-related quality of life .................................................................. 22

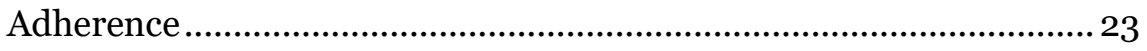

AIM OF THE THESIS.......................................................................... 25

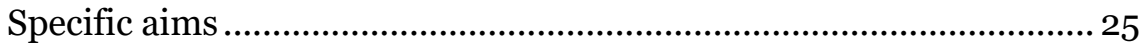

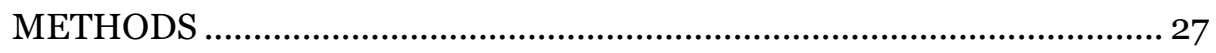

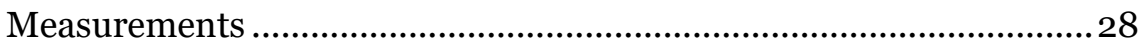




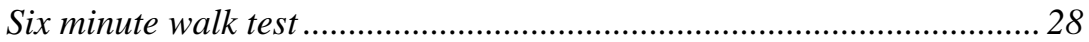

Symptom-limited bicycle ergometer test ................................................. 29

Health-related quality of life .................................................................... 29

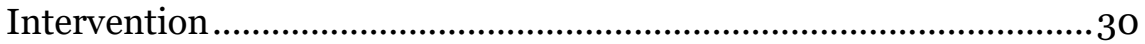

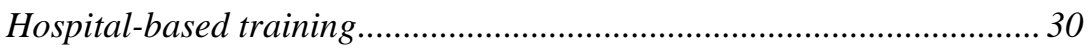

Home-based training ............................................................................ 32

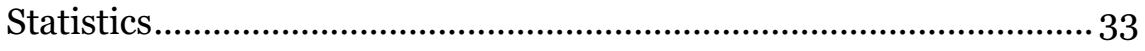

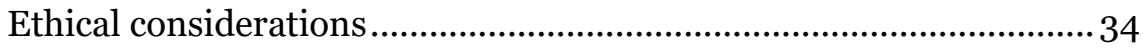

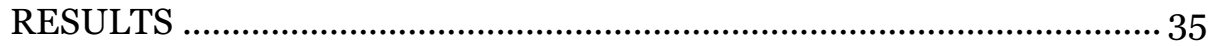

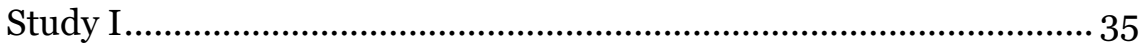

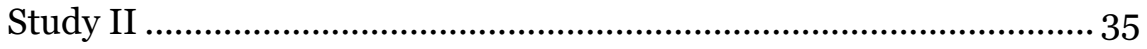

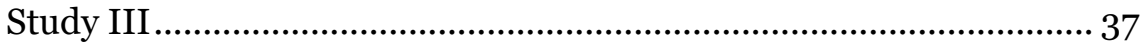

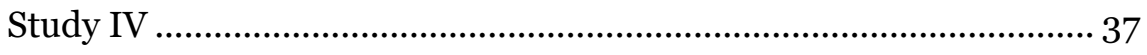

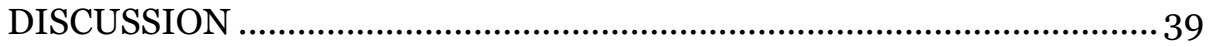

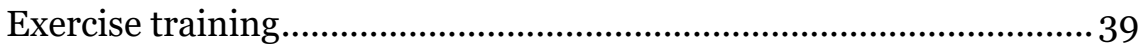

Functional testing................................................................................. 41

Health-related quality of life .................................................................. 43

Adherence and barriers .......................................................................... 43

Home- and hospital setting................................................................ 45

Life-long training programme ......................................................... 45

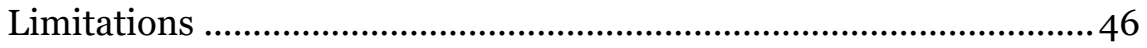

CONCLUSIONS …............................................................................. 49

Clinical implications............................................................................ 49

Future research and development .....................................................5

ACKNOWLEDGEMENT.......................................................................51

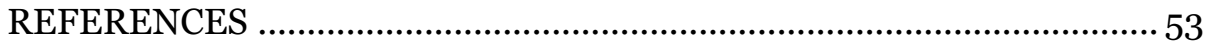




\section{ABSTRACT}

Patients with heart failure (HF) suffer from symptoms such as dyspnea, fatigue and reduced quality of life, which affect their physical function and often lead to immobilization and poor survival prognosis. Exercise training in cardiac rehabilitation should be offered to every patient with HF and can be performed both in a hospital-setting and with a home training programme. Exercise, in patients with HF, improves physical function and functional capacity as well as health-related quality of life (HRQoL) and reduces the need for hospital care. There are several barriers against participating in exercise based cardiac rehabilitation despite information about its benefits. The patient may anticipate not being able to exercise, that the exercise would be too hard, lives far away or has not been referred.

Aim: The aim of this thesis was to evaluate the effects of exercise in heart failure patients, of a one-year training programme, with hospital-based training followed by a home-based setting or only home-based, with special emphasis on peripheral muscle training (PMT). Furthermore, to study frequently used methods for evaluation of the effects, i.e the 6-minute walk test and instruments for estimating health-related quality of life.

Methods and findings: In study I, PMT was evaluated and the PMT programme in a hospital-setting (with equipment) and subsequent homebased training (with elastic bands) was compared with solely home-based training, over 1 year. At follow-up every third month, duplicated six minute walk test (6MWT) and two HRQoL questionnaires were used. The walking distance increased significantly after three months in both groups and was maintained thereafter. Also HRQoL increased but at different time points. In study II, PMT was compared with interval training on an ergometer bike/free walking. Both groups started under supervision of a physiotherapist in a hospital-setting, for three months and thereafter at home for nine months. The same measurements were used as in study I. Neither walking distance nor HRQoL changed over the study period. However, this may be regarded as a positive effect in the light of the known progressive nature of heart failure. In study III, the 6MWTs from study I and II were used to evaluate the necessity of performing duplicated 6MWTs in follow-ups clinically and for research purposes. We found that it is sufficient to perform one 6MWT. In study IV, both 6MWT and HRQoL forms from study I and II were used to investigate the relationship between walking distance and perceived HRQoL in HF patients. Patients with shorter walking distance, than the group median, experienced poorer general HRQoL but not HRQoL related to HF, than the higher performing 
half of the study group. There were no longitudinal trends in these relationships.

Conclusion: PMT can be used as an exercise modality in patients with HF, both in hospital and at home, and may be evaluated with a single 6MWT. Shorter walking distance was related to a lower general HRQoL as judged by the patients but there was no significant relation between short walking distance and the HF-related HRQoL. Individualizing the training programme and methods, and offering the choice of exercise modality and the possibility of exercising at home, might be a way to increase adherence in cardiac rehabilitation. 


\section{SVENSK SAMMANFATTNING}

Patienter med hjärtsvikt besväras av andfåddhet och trötthet vilket påverkar deras fysiska funktion och ofta leder till immobilisering, nedsatt livskvalitet och dålig prognos. Träning inom hjärtrehabilitering bör erbjudas alla patienter med hjärtsvikt och kan utföras såväl på sjukhus som hemma med hemträningsprogram. Träning vid hjärtsvikt förbättrar fysisk funktion och funktionell kapacitet, hälsorelaterad livskvalitet, och minskar behovet av vård på sjukhus. Det finns många barriärer till att delta i hjärtrehabilitering trots information om vinster, $\mathrm{t}$ ex att patienten tror sig inte klara av att träna, bor långt ifrån, har inte fătt remiss för att nämna några.

Syfte: Syftet med avhandlingen var att utvärdera effekterna av ett träningsprogram för patienter med hjärtsvikt under 1 år, träning på sjukhus följt av hemträning eller enbart hemträning. Ett specifikt syfte var att utvärdera perifer muskelträning (PMT) som en möjlig, lämplig träningsmetod för hjärtsviktspatienter. Vidare var syftet att utvärdera effekten av sex minuters gångtest och hälsorelaterad livskvalitet.

Metod och resultat: I studie I utvärderades PMT och jämförde träning på sjukhus (med redskap) med efterföljande hemträning (med elastiska band) med enbart hemträning under 1 år. Vid utvärdering var tredje månad användes dubbla sex minuters gångtest och frågeformulär om livskvalitet. Gångsträckan ökade signifikant efter träning och höll i sig hela träningsperioden i båda grupperna. Även livskvaliteten ökade men vid olika tidpunkter. I studie II, jämfördes PMT med intervallträning på ergometercykel/promenader. Båda grupperna tränade under ledning av fysioterapeut i tre månader och därefter hemma upp till 1 år. Samma utvärdering som i studie I. Gångsträcka och livskvaliteten ändrade sig inte under studietiden. Det kan dock ses som en positiv effekt eftersom hjärtsviktspatienter vanligen försämras över tid. I studie III, användes gångtesten från studie I och II för att utvärdera om det är nödvändighet att utföra dubbla sex minuters gångtest vid utvärdering. Ingen kliniskt betydelsefull skillnad sågs mellan gångtest ett och två. I studie IV, användes både gångtest och livskvalitetsformulär, från studie I och II, för att undersöka samband mellan gångsträcka och upplevd livskvalitet och om detta samband ändrades med tiden. Patienter med kortare gångsträcka upplevde sämre allmän hälsorelaterad livskvalitet men inte livskvalitet relaterad till hjärtsvikten, någon kliniskt signifikant förändring över tid kunde inte påvisas. 
Konklusion: Perifer muskelträning kan användas som en säker träningsform för patienter med hjärtsvikt, både på sjukhus och som hemträning och kan utvärderas med endast ett sex minuters gångtest. Patienter med kortare gångsträcka upplever sämre allmän livskvalitet vilket förefaller relativt oberoende av de olika testtidpunkterna. 


\section{LIST OF PAPERS}

I. Lans C, Cider Å, Nylander E, Brudin L. Peripheral muscle training with resistance exercise bands in patients with chronic heart failure. Long-term effects on walking distance and quality of life; a pilot study. ESC Heart Failure 2018;5:241-248.

II. Lans C, Cider $\AA$, Nylander E, Brudin L. Neither hospital-based nor home-based aerobic or peripheral muscle training improved walking distance or health-related quality of life during a one year follow-up in heart failure patients. In manuscript.

III. Lans C, Cider Å, Nylander E, Brudin L. Test-retest reliability of sixminute walk tests over a one-year period in patients with chronic heart failure. Clin Physiol Funct Imaging. 2020;40:284-289.

IV. Lans C, Cider Å, Nylander E, Brudin L. Six minute walk test versus health related quality of life in patients with chronic heart failure. Submitted.

Published articles have been reprinted with the permission of the copyright holders. 


\section{ABBREVIATIONS}

6MWD Six minute walking distance

6MWT Six minute walk test

ATS American Thoracic Society

CEG Cycling Exercise Group, study II

COV Coefficient of variation

CPET Cardiopulmonary exercise test

CR-10 Borg scale, Category Ratio 0-10

EF Ejection fraction

GT Group-based training group, study I

HF Chronic heart failure

HT Home-based training group, study I

HRQoL Health related quality of life

ICC Intra class correlation

MLHFQ Minnesota Living with Heart Failure Questionnaire

NYHA New York Heart Association functional classification

PEG Peripheral Exercise Group, study II

PMT Peripheral muscle training

RPE Borg scale, rating of perceived exertion 6-20

SF-36 SF-36v1 ${ }^{\mathrm{TM}}$, Short Form-36 version1

PF Physical Functioning

RP Role-Physical

BP Bodily Pain

GH General Health

VT Vitality

SF Social Functioning

RE Role-Emotional

MH Mental Health

PCS Physical component summary score

MCS Mental component summary score 


\section{DEFINITIONS}

Exercise

Exercise capacity

Exercise intolerance

Functional capacity

Health

Physical function

Physical activity

Physical fitness

Quality of life

$\mathrm{VO}_{2}$

$\mathrm{VO}_{\text {2peak }}$
Physical activity that is planned, structured, repetitive, and purposive in the sense that improvement or maintenance of one or more components of physical fitness is an objective (1).

The maximum amount of physical exertion that a subject can sustain. Expressed as peak $\mathrm{VO}_{2}(2)$.

An impairment in the capacity to accomplish physical activities followed by increased breathing and fatigue (3).

The ability to perform aerobic work as defined by the maximal oxygen uptake (2).

A state of complete physical, mental and social wellbeing not merely the absence of disease or infirmity (4).

The capacity of an individual to carry out the physical activities of daily living (5).

Any bodily movement, produced by skeletal muscles, that results in energy expenditure (1).

Physical fitness is a set of attributes that people have or achieve which relate to the ability to perform physical activity (1).

An individual's perception of their position in life in the context of culture and value systems in which they live and in the relation to their goals, expectation, standards and concerns" is also an opportunity to achieve personal goals (6).

Oxygen uptake (7).

Highest oxygen uptake achieved (7). 


\section{INTRODUCTION}

A sedentary behavior and physical inactivity are responsible for about $6 \%$ of all death globally and a risk factor for cardiovascular disease, but a modifiable risk factor (8). Physical activity and exercise in leisure time are described as the best buy for public health (9). Cardiac rehabilitation in patients with chronic heart failure (HF) is underused throughout the world (10) and a priority of class $1 \mathrm{~A}$ recommendation in both the European and American guidelines (11-13). In the guidelines of heart disease and treatment by the National Board of Health and Welfare in Sweden there is a priority 3 on a recommendation scale (a 10-point scale, 1 has the highest priority, priority 1-3 is considered mandatory to the patient) which means that every patient with HF should be offered cardiac rehabilitation with a customized individually prescribed exercise programme (14). The implementation of cardiac rehabilitation is about to change and is now increasing in Europe. The ExtraHF survey study concluded that out of 170 centers in Europe (1 center in Sweden), 52\% offered out-patient exercise training cardiac rehabilitation and $18 \%$ could also offer a home-based programme (15). Adherence to exercise training tends to decrease over time (16), therefore it is important to find an exercise modality that can meet exercise guidelines, patient's preferences, and which may be performed lifelong.

The studies in this thesis aimed at increasing the knowledge on different modes of exercise for use in cardiac rehabilitation in patients with heart failure, with focus on a long-term perspective, and to evaluate methods for characterising limitations and impairment of physical function coupled to heart failure. 


\section{BACKGROUND}

\section{Heart failure}

\section{Definition}

The definition of heart failure (HF), according to European Society of Cardiology, is "a structural and/or functional cardiac abnormality, resulting in a reduced cardiac output and/or elevated intracardiac pressures at rest or during stress" (11). Heart failure means that there is an inability of the heart to maintain a cardiac output with normal filling pressure which is sufficient to provide the body tissues of adequate blood supply $(17,18)$.

The prevalence of HF is estimated, in the western world, to 1-2 \% and increases considerably with age, $(10,17,18)$ in Sweden prevalence is about $2 \%$ in the total population (19), and as high as $10 \%$ in patients above an age of 80 years $(14,20)$. The incidence is about $2-5$ per 1000 habitants per year $(19,21)$. The prognosis of $\mathrm{HF}$ is poor, with a 5 -year survival rate of approximately 50\% (19).

\section{Pathophysiology}

Heart failure is a syndrome with a multifaceted complex pathophysiology.

Most heart diseases in advanced stages can cause HF, since HF itself is a syndrome and not an independent diagnosis $(18,22)$. Coronary artery disease, hypertension, atrial fibrillation, valve disease, separate or in combination, are the most common causes of HF in the western world (17, 22, 23). Therefore, it is important to find out the underlying cause of HF.

Heart failure is mainly caused by two different disorders of the heart function, diastolic and systolic dysfunction. In diastolic dysfunction the filling phase is disturbed and, in the case of systolic dysfunction the emptying capacity of the heart is reduced, most commonly due to decreased contractility $(24,25)$. The left ventricular ejection fraction (EF) is used to establish the degree of systolic ventricular function, calculated as the stroke volume divided by the end-diastolic volume in percent $(17,26)$. Ejection fraction is an important parameter since it has a prognostic value, lower $\mathrm{EF}$ 
means worse prognosis and survival (23). However, it correlates poorly with exercise capacity (27).

Most often, the heart dilates as a result of increased filling pressure and thus filling volume in order to maintain the stroke volume according to the Frank-Starling principle $(7,26)$. Initially, this is an adequate compensation mechanism, but increased volume of the heart also leads to an increased load and reduced efficiency. To compensate for the disturbed ventricular function, the peripheral circulation relocates. The blood is redistributed to the most vital organs. Central mechanisms provide increased sympathetic tone which in turn leads to increased contractility and heart rate as well as a peripheral vasoconstriction. When the peripheral resistance increases, the heart also has an increased resistance, afterload, to work towards. This leads to progressive changes in the periphery (See section "Skeletal muscle", page 16$)(25,28)$.

By tradition, HF has been defined as a failure of the contractile function, but later on it has been recognized that HF can occur even with a normal or near normal EF (23). Both diastolic and systolic dysfunction may occur at the same time $(20,22)$.

\section{Categories}

Heart failure is classified into three categories, Figure 1:

- Heart Failure with REDUCED left ventricular ejection fraction (HFrEF), the EF is $40 \%$ or less. Also classified as systolic heart failure. The pumping ability is reduced.

- Heart Failure with PRESERVED ejection fraction (HFpEF) where the $\mathrm{EF}$ is $\geq 50 \%$. This is the diastolic heart failure. The pumping ability is normal but the filling function is impaired.

- Heart failure with MID RANGE ejection fraction (HFmrEF) where the $\mathrm{EF}$ is between 40 and $49 \%$. This is a mix of the systolic and diastolic heart failure $(11,29,30)$. 
Figure 1. Categories of heart failure

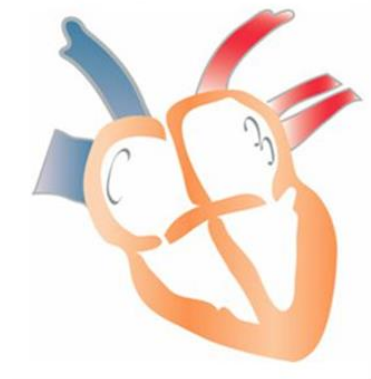

Diastolic heart failure

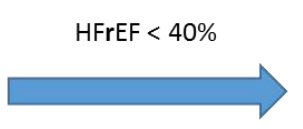

HFmrEF $40-49 \%$

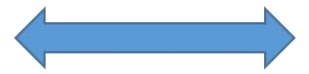

HFpEF $\geq 50 \%$

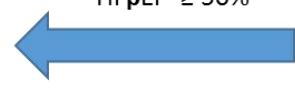

Evidence for efficacious management and exercise training in patients with $\mathrm{HFpEF}$ is limited and less documented in literature than for patients with $\operatorname{HFrEF}(23,31)$.

In this thesis, patients with HFrEF are studied.

\section{Symptoms and severity}

The clinical symptoms are often diffuse, especially in the early stages, and it can be difficult to differ HF from other diseases such as lung diseases. Early symptoms can be fatigue and dyspnea and may occur already with exertion at low workload or just in different body positions (25). The fatigue may be due to decreased cardiac output and dyspnea may be a sign of elevated filling pressure. Physical function is affected, for example, by immobilization and reduced health-related quality of life resulting in symptoms of exercise intolerance and increased time to recover after exercise, Table $1(11,12)$.

Table 1. Most typical symptoms and signs in $\operatorname{HF}(11,32)$.

\begin{tabular}{lll}
\hline Clinical symptoms & Specific signs & Functional symptoms \\
\hline Breathlessness & Elevated jugular venous & Immobilized \\
Fatigue & pressure & Reduced physical fitness \\
Orthopnea & Hepatojugular reflux & Reduced exercise \\
Paroxysmal nocturnal & Third heart sound & tolerance \\
dyspnea & (gallop rhythm) & Fatigue, tiredness, \\
Ankle swelling & Laterally displaced & $\uparrow$ recover time after \\
& apical impulse & exercise \\
& & Low functional capacity \\
& & Low quality of life \\
\hline
\end{tabular}


These are the most typical and specific symptoms and signs. In addition, there are less typical symptoms and less specific signs not mentioned here.

To specify the degree of HF, a subjective functional classification by the New York Heart Association, (NYHA) is commonly used in randomized trials and in the clinic. The level of severity and impairment of physical activity is divided into four classes (33), Table 2.

Table 2. New York Heart Association functional classification, adopted from Marvin HM (33).

\begin{tabular}{l|l}
\hline Severity & \multicolumn{1}{c}{ Physical activity } \\
\hline Class I & $\begin{array}{l}\text { No limitation of physical activity. Ordinary physical activity does } \\
\text { not cause undue breathlessness, fatigue, or palpitations. }\end{array}$ \\
\hline Class II & $\begin{array}{l}\text { Slight limitation of physical activity. Comfortable at rest, but } \\
\text { ordinary physical activity results in undue breathlessness, fatigue, } \\
\text { or palpitations. }\end{array}$ \\
\hline Class III & $\begin{array}{l}\text { Marked limitation of physical activity. Comfortable at rest, but } \\
\text { less than ordinary physical activity results in undue } \\
\text { breathlessness, fatigue, or palpitations. }\end{array}$ \\
\hline Class IV & $\begin{array}{l}\text { Unable to carry on any physical activity without discomfort. } \\
\text { Symptoms at rest can be present. If any physical activity is } \\
\text { undertaken, discomfort is increased. }\end{array}$ \\
\hline
\end{tabular}

\section{Skeletal muscle}

Most patients with HF have developed skeletal muscle abnormalities. Skeletal muscle wasting, such as sarcopenia and myopathy occurs in 30$50 \%$ of patients with HFrEF, as a result of impaired mobility and symptoms $(11,34)$. Moreover there is a mitochondrial dysfunction, fewer muscle fibers type 1 (switch from type 1 to type 2 fiber), and decreased muscular capillary network which leads to impaired, both exercise and functional, capacity $(28,34,35)$.

The muscle metabolism is altered in HF due to early accumulation of metabolites in the skeletal muscles and contributes to the reduced exercise tolerance. Breathlessness increases during exercise; breathing is controlled by several mechanisms, among others through afferent nerves (via chemoreceptors) from the skeletal muscles, the so-called ergo reflex or metaboreflex. The metaboreflex is over-activated in patients with HF, which leads to increased dypnea already at low physical activity or even in rest $(32,36)$. 
A key role of the periphery has emerged, generating the 'muscle hypothesis', where exertional dyspnea and fatigue are resulting from skeletal muscle pathophysiology, also because of deconditioning (28).

\section{Exercise intolerance and capacity}

A hallmark of HF is exercise intolerance. Exercise intolerance is defined as an impairment in the capacity to accomplish physical activities followed by increased breathing and fatigue $(3,37)$. Together the pathophysiological changes in the cardiovascular, muscular and respiratory systems contribute to the exercise intolerance, due to early onset of muscle fatigue, and a high degree of breathlessness $(36,38,39)$.

Exercise intolerance is a feature in $\mathrm{HF}$ and is associated with low quality of life (QoL) and poor prognosis. Clinically, exercise intolerance appears as breathlessness and fatigue (37). Piepoli et al. (39) claim that exercise intolerance can be successfully tackled by regular exercising.

Exercise capacity and functional capacity are often used as the same term, and need to be defined. According to Arena et al. (2), exercise capacity could be defined as "the maximum amount of physical exertion that a subject can sustain" and functional capacity may be defined as "the ability to perform aerobic work as defined by the maximal oxygen uptake". However, both exercise capacity and functional capacity are affected by limitations in the cardiovascular system $(2,3,37)$.

\section{Treatment}

The aim of treatment of HFrEF is to alleviate symptoms, improve quality of life, prevent progression, decrease hospital readmission and prolong survival. The treatment should contain both pharmacological treatment and non-pharmacological treatment, such as nursing clinic (consists of information, medical titration, risk stratification, dietary advice etc) and participation in exercise based cardiac rehabilitation, led by a physiotherapist (40, 41). Recommended pharmacological treatment includes e.g. beta-blockers, ACE-inhibitors and diuretics $(42,43)$. Implantable cardiac device therapy, such as pacemaker, cardiac resynchronization therapy (CRT) and implantable cardioverter defibrillator (ICD) might be needed and is valuable for some patients with HF. In a more advanced stage there may be need for a mechanical assist device and heart transplantation (11). 


\section{Physical activity and exercise}

Exercise is a subcategory of physical activity, not synonymous. Since the term physical activity often is used as a collective expression, there is a need to define different degrees of physical activity:

Physical activity is defined as any bodily movement, produced by skeletal muscles, that results in energy expenditure.

Exercise is physical activity that is planned, structured, repetitive, and purposive in the sense that improvement or maintenance of one or more components of physical fitness is an objective.

Physical fitness is a set of attributes that people have or achieve which relate to the ability to perform physical activity (1).

This thesis studies effects of exercise, not physical activity, in daily life.

\section{Recommendations of physical activity and exercise}

The global and national recommendations for physical activity and exercise in healthy adults and for patients with heart failure are similar $(4,11,13)$.

Physical activity counselling for patients with HF is to be physical active at least 30-6o $\mathrm{min} /$ day at a moderate intensity most days of the week $(41,44)$. A study by Dontje et al. (45) showed that approximately half of the patients with HF had a sedentary lifestyle and took fewer than 5000 steps/day, and suggested that patients were sedentary if they performed less than 30 $\mathrm{min} /$ day of moderate to vigorous activities (45).

The latest recommendations of exercise consist of both aerobic and resistance training, and in elderly, balance exercises is added (8). All healthy adults and patients with cardiac disease should perform exercises for at least 150 minutes distributed over the week at a moderate level of exertion. Moreover, resistance exercises may be added, 2-3 week but should not replace the aerobic exercising (13).

If the recommendations cannot be achieved, due to age or disease, the recommendation is to be as active as the condition allows; activities may need to be adapted to the condition as well as to the individual (4).

\section{Aerobic exercise}

Simplified, aerobic exercise means exercising with enough oxygen supply and without oxygen deficit via the aerobic metabolism. In general, the intensity of the exercise should be moderate over a longer period of time. 
This can be performed in different ways: continuous exercising or in intervals. Continuous exercising means training at a sustained low to moderate level throughout the training session; interval exercising means alternating the exercise intensity between higher and lower in different time intervals $(7,46,47)$.

\section{Muscular exercise}

Muscular exercising involves both the peripheral muscles (upper and lower extremities) and the muscles of the torso (including postural muscles). The aim of the exercising can vary depending on the purpose of the training; this is regulated by the number of repetitions per exercise, sets and intensity $(7,46)$. The aim of muscular exercising might be to improve strength, endurance, maintance of muscular effects and increase local circulation. In summary, the same muscles and exercises is used to achieve different purposes. Resistance training is defined, by Fleck and Kreamer (48), "as a type of exercise that requires the body's musculature to move (or attempt to move) against an opposing force, usually presented by some type of equipment".

The resistance training encompasses the use of own body weight, free weights or elastic band $(48,49)$.

Peripheral muscle training in this thesis aimed to use an isolated muscle mass with a low load and high number of repetitions to increase peripheral circulation in a specific skeletal muscle while imposing only a low load on the cardio-respiratory system (50-52).

\section{Exercise training in patients with heart failure}

Exercise training in patients with HF improves e.g. skeletal muscle, peripheral vascular function and central hemodynamic function, which together constitute $\mathrm{VO}_{2}$, as well as functional capacity and walking distance, Table $3(53-55)$. Oxygen uptake $\left(\mathrm{VO}_{2}\right)$ is the result of cardiac output and arterio-venous oxygen $\left(\mathrm{a}-\mathrm{vO}_{2}\right)$ difference at physical activity, higher workload requires higher $\mathrm{VO}_{2}$.

Better $\mathrm{VO}_{\text {2peak }}$ (highest $\mathrm{VO}_{2}$ achieved) is associated with lower mortality and hospitalizations $(56,57)$. The benefits of exercise training also include improved HRQoL (58).

Exercise training is broadly recognized as a valuable adjunct in the care of patients with $\mathrm{HF}$ and is a key component in cardiac rehabilitation $(41,56$, $59,60)$. 
Table 3. Important effects of exercise training in $\operatorname{HF}(11,61)$.

\begin{tabular}{l|l}
\hline \multicolumn{1}{c|}{ Aerobic training } & \multicolumn{1}{c}{ Resistance training } \\
\hline$\uparrow$ VO $_{2 \text { peak }}$ & $\uparrow$ muscle strength \\
$\uparrow$ anaerobic threshold & $\uparrow$ muscle endurance \\
$\uparrow$ peripheral perfusion & $\uparrow$ oxidative capacity \\
$\uparrow$ 6-minute walk distance & $\uparrow 6$ minute walk distance \\
$\uparrow$ quality of life & $\uparrow$ quality of life \\
$\downarrow$ hospital readmission & Different effects on $\mathrm{VO}_{2 \text { peak }} \uparrow \downarrow$ \\
& and $\rightarrow$ \\
\hline
\end{tabular}

Table 4. Classification of intensity. Adapted from ACSM (46).

\begin{tabular}{|c|c|c|c|c|}
\hline Intensity & $\% \mathrm{HR}_{\max }$ & $\begin{array}{c}\text { RPE } \\
\text { (6-20 scale) }\end{array}$ & $\begin{array}{c}\text { RPE on CR-10 } \\
\text { (1-10 scale) }\end{array}$ & Talk test \\
\hline Light & $<64$ & $<12$ & $3-4$ & $\begin{array}{l}\text { Comfortable } \\
\text { speech is possible }\end{array}$ \\
\hline Moderate & $64-77$ & $12-13$ & $5-6$ & $\begin{array}{l}\text { Speech possible } \\
\text { with some difficulty }\end{array}$ \\
\hline Vigorous/Hard & $77-94$ & $14-16$ & $7-8$ & $\begin{array}{l}\text { Speech limited to } \\
\text { short phrases }\end{array}$ \\
\hline Very Hard & $>94$ & $17-20$ & $>9$ & $\begin{array}{l}\text { Speech is very } \\
\text { difficult }\end{array}$ \\
\hline
\end{tabular}

HR, Heart Rate; RPE, Rating of Perceived Exertion; CR-10, Category Rating scale 0-10

\section{Cardiac rehabilitation}

Cardiac rehabilitation is a structured and multidimensional intervention with interplay of medical, psychological and behavioural factors facing the patients, managed by a multidisciplinary team, Figure $2(41,62)$. The multidisciplinary strategy is to e.g. stabilize or slow down disease progression, reduce symptoms and foster an active lifestyle $(53,63)$. 
Figure 2. Services and key components in cardiac rehabilitation (CR). Adapted from Balady et al. (41).

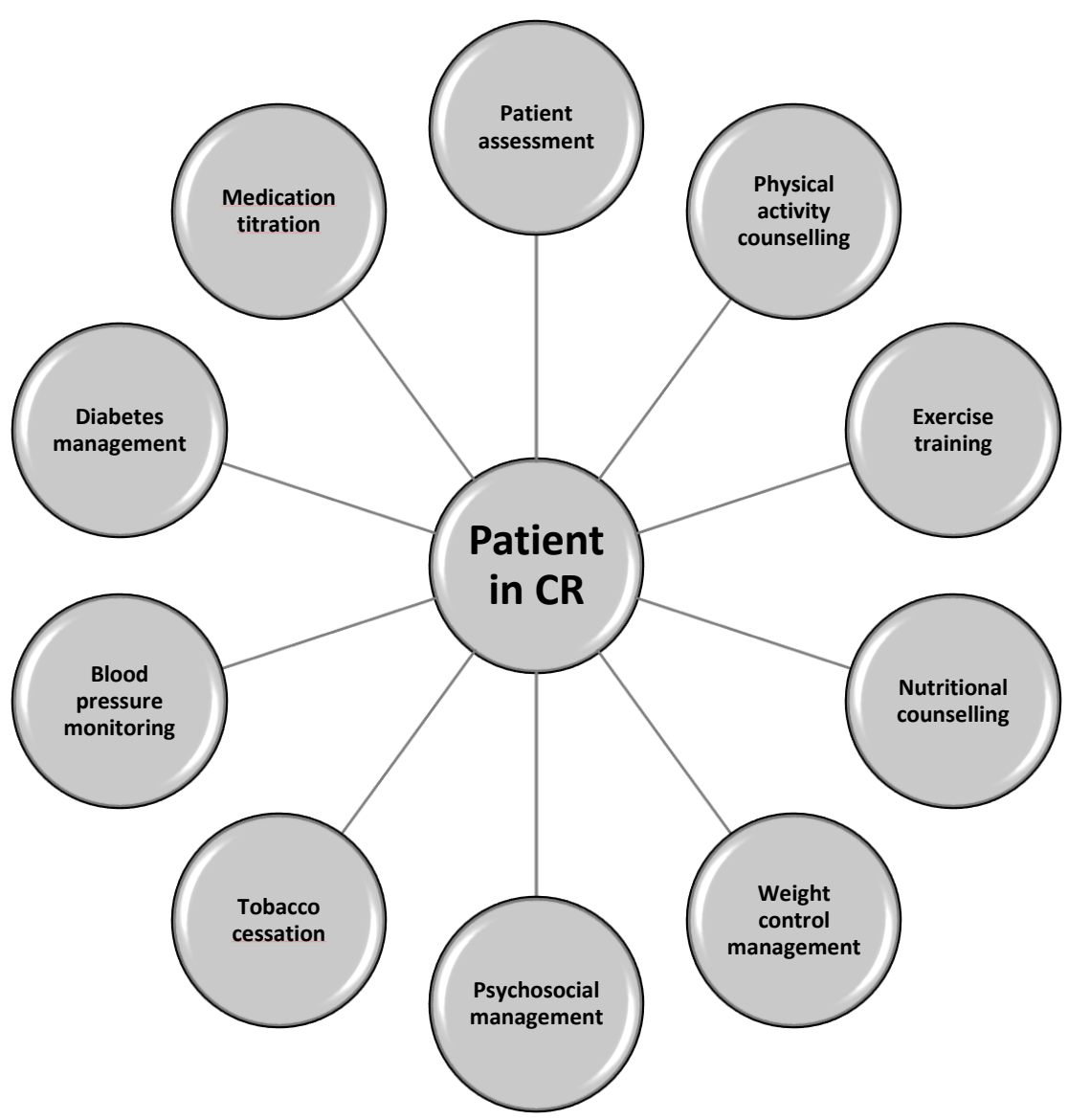

\section{Physiotherapy management exercise based cardiac rehabilitation}

The main components in physiotherapy management is exercise training, and a cornerstone of cardiac rehabilitation (56). According to the guidelines (11-13), patients with heart failure should be offered participation in an exercise based cardiac rehabilitation, and yet it is underutilized. Before the onset of a cardiac rehabilitation programme, the patients precede through a clinical evaluation, risk stratification and physical testing $(40,44,59)$. In Sweden the physical testing is usually performed by a physiotherapist. Participation in a hospital-setting rather than home-based training is the most common (60). 
Based on the results of physical testing the physiotherapist gives the patients individualized exercise training recommendations consisting exercise training-, goals, content, method and frequency, intensity, time and type; these four components constitute the FITT-principle, Table 5 (64).

Table 5. FITT recommendations for patients with $\operatorname{HF}(13,41,46)$.

\begin{tabular}{|c|c|c|c|}
\hline \multirow{6}{*}{ E } & & Aerobic activity & Resistance activity \\
\hline & Frequency & 3-5 times/week & 2-3 times/week \\
\hline & Intensity & $\begin{array}{l}40-80 \% \mathrm{VO}_{2 \text { peak }} \\
\mathrm{RPE} 12-17\end{array}$ & $\begin{array}{l}10-15 \text { reps in } 1-3 \text { sets } \\
\text { RPE }<15(40-60 \% \text { of } 1 R M)\end{array}$ \\
\hline & Time & $\begin{array}{l}20-60 \text { minutes, } \\
\text { progressively increased }\end{array}$ & $\begin{array}{l}\text { 1-3 sets of } 8-10 \text { exercises, } \\
\text { upper and lower body } \\
\text { exercises, balance exercises } \\
\text { should be included }\end{array}$ \\
\hline & Type & $\begin{array}{l}\text { Stationary cycling, free- } \\
\text { walking, biking, running } \\
\text { etc. }\end{array}$ & $\begin{array}{l}\text { Machines, free weights, } \\
\text { body weight, resistance } \\
\text { band. }\end{array}$ \\
\hline & \multicolumn{3}{|c|}{ Each session should include warm-up and cool-down exercises } \\
\hline
\end{tabular}

\section{Health-related quality of life}

There is no clear definition of the term health-related quality of life (HRQoL). Health-related quality of life and quality of life (QoL) are often used interchangeable (65). The definitions of health (from 1948) and QoL (from 1995), according to WHO:

Health: "A state of complete physical, mental and social well-being not merely the absence of disease or infirmity" (4).

QoL: "An individual's perception of their position in life in the context of culture and value systems in which they live and in the relation to their goals, expectations, standards and concerns" is also an opportunity to achieve personal goals (6).

The concept of health and QoL encompasses most aspects of life and is difficult to provide a strict definition for the terms together in HRQoL (4, 6, 65). HRQoL is an evaluation of QoL and its relationship with health.

Both health and QoL are subjective parameters commonly used together as HRQoL as an outcome in studies in patients with HF. To cover the spectrum of health and QoL, both a generic and a disease-specific questionnaire can be chosen to measure $\operatorname{HRQoL}(66,67)$, a generic with 
reference values in healthy population for comparison and a diseasespecific to evaluate the impact of an intervention.

Patients with HF experience low HRQoL due to persistent symptoms despite optimal treatment (67). Patients with HF estimate the second lowest physical health measured by the SF- 36 compared to patients with other chronic diseases (68). Meta-analysis $(58,69)$ have found that exercise training improves the quality of life score measured with Minnesota living with heart failure questionnaire (MLHFQ).

\section{Adherence}

According to WHO (70) the definition of adherence is the extent to which a person's behavior is corresponding with agreed recommendations from a health care provider. The recommendations are not only about taking medication but also encompass lifestyle changes, as increasing physical activity.

According to the ExtraHF survey on implementation of exercise training in HF patients in Europe, which includes 41 countries, 170 centers and over 76000 patients, about 50\% are denied exercise therapy (15). Barriers for adherence in cardiac rehabilitation can be related to e.g. patient, health care team/system and condition, Table $6(15,71,72)$. 
Table 6. Barriers for exercise in patients with HF. Adapted from Conraads et al. (71).

\begin{tabular}{l|l}
\hline & Barriers \\
\hline Patient related & Older age \\
Low level of education \\
Low socio-economic status \\
Anxiety and depression \\
Logistical problems \\
Lack of motivation \\
Lack of insight into benefits \\
Lack of time
\end{tabular}

When patients have problems with adherence, the patients need to be supported, not blamed (70). There are several suggestions to help the patients increase adherence to exercise, such as face-to-face contact regulary with e.g. physiotherapist, group exercise sessions, feedback, exercise equipment provided for home-based training, to mention some (16). 


\section{AIM OF THE THESIS}

The general aim of this thesis was to evaluate exercise training and testing in patients with chronic heart failure with focus on different exercise modalities, walking distance and HRQoL and the correlations between them. The overall goal was to contribute knowledge to this field, which would be applicable in clinical practice and thereby benefit patients with HF.

\section{Specific aims}

Study I: To describe a PMT programme with resistance bands in a home-based setting and to evaluate the effects on walked distance and HRQoL, in patients with HF, over a 12 month period. The second aim was to compare home-based training versus group-based supervised training (in a hospital-based setting during the first 3 months), subsequent over the 12 month period.

Study II: To compare the PMT programme from study I with an aerobic training programme. Initially, both groups started with supervised exercise training in a hospital-setting for 3 months and thereafter exercising in a home-based setting for 9 months.

Study III: To evaluate if it is necessary with duplicated walk tests for evaluation over time using test-retest reliability assessment of the 6MWT in patients with $\mathrm{HF}$.

Study IV: To define the relationship between the 6 minute walked distance (measured with 6MWT) and self-reported HRQoL measured with both a generic and a disease specific questionnaire. 


\section{METHODS}

This thesis is based on four studies described in Table 7 and Figure 3. All patients were recruited from the department of cardiology or department of clinical physiology, Kalmar county hospital. Both exercise testing and training were performed at the department of physiotherapy, Kalmar county hospital.

Table 7. Overview of studies I-IV.

\begin{tabular}{c|l}
\hline Study & \multicolumn{1}{|c}{ Design and study criteria } \\
\hline I & $\begin{array}{l}\text { Prospective longitudinal randomized controlled study } \\
\text { Inclusion criteria: Heart failure }>3 \text { months, stable drug therapy, NYHA } \\
\text { II-III, EF } \leq 40 \%, \text { Age } \leq 80 \text { years } \\
\text { Exclusion criteria: Physical or mental disorder limiting testing or } \\
\text { training, concomitant disease e.g. chronic obstructive pulmonary } \\
\text { disease and diabetes mellitus } \\
\text { Prospective longitudinal randomized controlled study } \\
\text { Inclusion criteria: Heart failure }>3 \text { months, stable drug therapy, NYHA } \\
\text { II-III, EF } \leq 40 \%, \text { Age } \leq 80 \text { years } \\
\text { Exclusion criteria: Physical or mental disorder limiting testing or } \\
\text { training, concomitant disease e.g. chronic obstructive pulmonary } \\
\text { disease and diabetes mellitus } \\
\text { Longitudinal reliability study } \\
\text { Data from study I and II } \\
\text { Prospective experimental longitudinal study } \\
\text { Data from study I and II }\end{array}$ \\
III
\end{tabular}


Figure 3. Flowchart over studies I-IV.

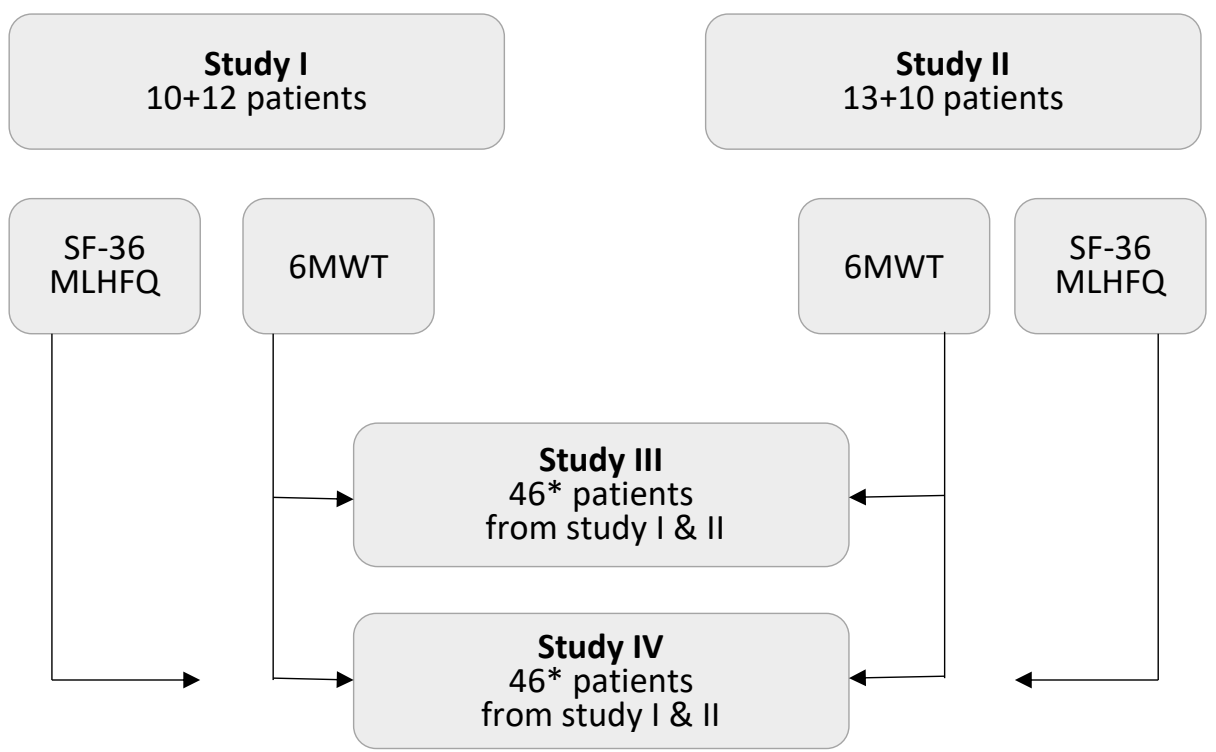

*1 patient, in study I, rejected further participation but gave permission to use baseline data. 6MWT, 6 minute walk test; MLHFQ, Minnesota Living with Heart Failure Questionnaire

\section{Measurements}

\section{Six minute walk test}

Walking distance was measured with an indoor standardized six minute walk test (6MWT). The 6MWT was performed in a flat, straight, 80-meter hospital corridor, without disturbance. Traffic cones were placed at each end of the course which was marked in 2.5 meter intervals to facilitate the distance count.

The standardized instructions were modified from ATS's recommendation (73), adapted for patients with HF. Before the 6MWT, oral instruction was given as to how to perform the test and how to use the Borg scales (74).

The patients were instructed to walk as far as possible in self-selected pace for 6 minutes. If needed, they were allowed to slow down or stop and rest, and continue walking when able to, but the time was still measured. They were not allowed to run. No encouragement was given during the test, but an oral signal was given when 1 minute remained.

Heart rate was monitored with a pulse transmitter attached to the chest with a display on the wrist (Polar@, Kempele, Finland), and was measured before and immediately after when walking stopped at 6 minutes. The 
patients also rated, on Borg's scales (74), their perceived exertion (RPE 620) and feelings of breathlessness and chest pain (CR-10). The 6MWTs were performed by a physiotherapist not otherwise involved in the studies. The patients performed the $6 \mathrm{MWT}$ twice at each occasion on the same day with a 45 minutes rest, in a seated position, in between.

In study I the second 6MWT was analysed, but in study II the walk test with longest distance was used in the analysis.

\section{Symptom-limited bicycle ergometer test}

In study II, before starting exercising, the patients in the cycling exercise group (CEG) also performed a bicycle ergometer test. The purpose was to obtain the highest heart rate for calculating the correct heart rate span during the exercise class. The bicycle ergometer test was, therefore, not repeated during the study period. The workload started at 30 Watt (W), for women, and $50 \mathrm{~W}$ for men, and increased stepwise every minute with $5 \mathrm{~W}$ (women) and 10W (men), respectively, until reaching 17 at Borg's RPE scale, which was the interruption criterion $(75,76)$.

\section{Health-related quality of life}

For evaluation of the health-related quality of life (HRQoL), validated and reliable Swedish versions of the short form Health Survey, SF-36v1 ${ }^{\mathrm{TM}}$ (SF36) and the Minnesota Living with Heart Failure Questionnaire (MLHFQ), were used to measure variations in generic (SF-36) and disease-specific (MLHFQ) health status during the study period. Both instruments are selfreported and were completed during the 45 -minute seated rest between the walk tests $(77,78)$.

\section{SF-36}

The SF-36 consists of 36 items and comprises eight dimensions which in turn can be divided into two summary components, physical (PCS) and mental (MCS) component score. Each dimension extends a scale ranging from 0 , worst perceived health status to 100 , best perceived health status. The eight subscales are: Physical Functioning (PF), Role-Physical (RP), Bodily Pain (BP) and General Health (GH) forming the PCS, and Vitality (VT), Social Functioning (SF), Role-Emotional (RE), Mental Health (MH), constituting the MCS (78-80). 


\section{MLHFQ}

The Minnesota Living with Heart Failure Questionnaire (MLHFQ) is a disease-specific questionnaire. A disease-specific form is designed to capture important aspects in a specific disease or group of patients, in this case adult patients with HF. The MLHFQ measures patients' perception of symptoms' impact on their daily life during the last month. The MLHFQ consists of 21 items in a total score of 0-105p: one physical domain (consists of 8 items, o-4op), and one emotional domain (consists of 5 items, $0-25 \mathrm{p}$ ); the other 8 items cover work, economics and sex, not included in a domain (81-83).

\section{Intervention}

In study I, both groups trained PMT, one group started in a hospital-setting followed by home-based training and the other group trained solely at home.

In study II, both groups started the exercise period in a hospital-based setting and continued with home-based training.

Both study I and II consisted of exercising and follow-ups during one year.

\section{Hospital-based training}

The exercise training programmes at the hospital were supervised by a physiotherapist and were conducted twice a week.

Table 8. Peripheral muscle training programme.

\begin{tabular}{l|l}
\hline \multicolumn{2}{c}{ Peripheral muscle training - In hospital and at home } \\
\hline \multicolumn{1}{c}{ Warm up } & M. gastrocnemius \\
Exercises in sitting and standing positions. & \multicolumn{1}{c}{ Pulley exercises or REP-band } \\
At home: walking on the spot. & Bilaterally in erect position \\
Exercises with free weights or REP-band & M. pectoralis major \\
Unilaterally standing or sitting & M. intercostalis \\
M. biceps brachii & M. rhomboids \\
Wrist extensor group. & M. triceps brachii \\
M. Quadriceps & M. gluteus maximus \\
$\quad$ Exercise using own body weight & Cool down for 5-10 minutes \\
Bilaterally in erect position. & Stretching exercises in both groups \\
\hline
\end{tabular}

REP-band, Resistive Elastic Product 


\section{Peripheral muscle training}

The exercises were individually tailored for each patient, based on a restricted HR, to exceed no more than 30 beats over resting HR, monitored with a pulse transmitter on the chest, displayed on a pulse-watch on the wrist (Polar®, Kempele, Finland), to achieve a high number of repetitions/exercise (30 times) with a low load, performed in 2 sets (50, 51). In case of atrial fibrillation, the exercise intensity for each muscle was based solely on RPE 15 in the working phase. The training regime was designed to include leg, arm and chest muscles, using pulleys, free weights, and body weight as resistance and was performed in the gym at the physiotherapy department for 60 minutes per session, Table 8.

Table 9. Aerobic training programme.

\begin{tabular}{l|c|c}
\hline \multicolumn{2}{c}{ Aerobic training - In hospital and at home } \\
\hline Interval training at hospital & Duration & RPE/HR\% \\
Warm up & 5 minutes & $11 / 40 \%$ \\
Interval circle consisting: & $15-45$ minutes & \\
$\quad$ High Interval & 90 seconds & $15 / 80 \%$ \\
$\quad$ Low Interval & 30 seconds & $13 / 60 \%$ \\
Cool down & 5 minutes & $11 / 40 \%$ \\
Free-walking at home & 5 minutes & 11 \\
Warm up & 35 minutes & $13-15$ \\
Free-walking & 5 minutes & 11 \\
Cool down &
\end{tabular}

RPE, rating of perceived exertion; HR, heart rate

\section{Cycling exercise}

The training protocol was adopted from an interval training study (84) on an ergometer bike. The patients accomplished an interval training program on an exercise bike, with 90 seconds of exercise and 30 seconds of active 'rest' but was modified to include a warm-up and a cool down period; in the active 'rest' between the intervals the patients continued biking but at a lower level of exhaustion.

The training programme was performed on an ergometer bike (Monark Ergomedic 818e, MonarkExercise, Vansbro, Sweden) and consisted of: five minutes warm-up at $40 \%$ of HRpeak or Borg RPE 11, a 90 s higher intensity interval and a 30 s active recovery phase (lower intensity) and finally a cool down for five minutes, at the same intensity as the warm-up phase, twice a week. 
Patients in sinus rhythm exercised using a HR monitor on the chest displayed on a pulse-watch (Polar $囚$, Kempele, Finland), corresponding to $80 \%$ of HRpeak at the baseline exercise test \pm 5 beats, during each interval, and recovery phase $60 \%$ of HRpeak. For patients with atrial fibrillation, the exercise intensity was chosen to correspond to exhaustion grade 15 according to the Borg RPE scale (74), approximately $80 \%$ of maximum, and $60 \%$ in the recovery phase, Table 9.

The training time was gradually increased from 15 to 45 minutes by adding 15 minutes of intervals per month. With warm-up and cool-down phases included the total exercise sessions were between 25 and 55 minutes. Patients adjusted individually the speed and load to reach adequate HR or RPE.

\section{Home-based training}

After completing the first training period under supervision in a hospitalsetting, a home-based training programme was tailored for each patients and prescribed for the remainder of the study period. Those patients in study I who began with home-based training, continued their training programme as before.

At follow-up, the load could be adjusted, but patients could contact the physiotherapist at any time if necessary. All patients were told to register the number of training sessions and perceived exertion in a logbook.

\section{Peripheral muscle training}

Patients who trained in the gym at the hospital continued with the same exercises but using elastic bands as resistance (REP-band®), (Resistive Elastic Product) Magister Corporation, Chattanooga, USA). The REPbands are available in 5 different resistors and was individually tailored for each patient. The training programme was prescribed to be performed in one set, $\geq 3$ times/week for 40 minutes per session, at an effort of RPE 13-15, Table 8 .

\section{Cycle training}

Patients who exercised on an ergometer bike switched the training programme to free-walking for 45 minutes per session, $\geq 3$ days/week, at an effort of RPE 13-15, Table 9. 


\section{Statistics}

Statistical analysis was performed using Statistica version 12 (StatSoft $囚$, Tulsa, OK, USA), MedCalc version 14.10 (MedCalc Software) and Excel 2013 (Microsoft Office, Redmond, WA, USA). The statistical significance level was set at $\mathrm{p}<0.05$ in all studies.

At baseline descriptive data, group differences were analysed using Fisher's exact test for categorical variables, and Mann-Whitney's U-test for continuous variables. The descriptive data was presented by numbers, percent, mean value and standard deviation, median and range, depending on characteristics and distribution of data $(85,86)$.

In study I and II, the power calculation was based on previously published results from similar studies; study II also included the results from study I for the power calculation. Calculations on an expected increase of $20 \%$ in walking distance with an SD of $30 \%$ indicated that a total of 24 patients should be included.

For comparison between groups over time, repeated measures ANOVA was used, with groups as categorical factors, and mixed factorial ANOVA followed by Duncan's post-hoc test in case of statistical significance (85, 86).

In study III, the Bland-Altman plot was used to describe the difference, in meters, between the paired 6MWTs (87). The intraclass correlation coefficient (ICC), and CI 95\%, was used for correlation between the duplicated 6MWT performed by the same subject and measurement error ( $\mathrm{S}_{\text {method}}$ ) together with the coefficient of variation (in\%) for intraindividual variability of the $6 \mathrm{MWT}(88)$. For interpretation of the ICC value $>0.75$ was considered acceptable (89) and $>0.90$ was considered excellent (90).

In study IV, each patient on each test occasion was allocated to a dichotomized group, based on the median walked distance, in percent, of all performed 6MWT of the predicted value.

The predicted walking distance in six minutes was calculated using Enright's formula (91):

Men $=(7.57 \times$ height $\mathrm{cm})-(1.76 \times$ weight $\mathrm{kg})-(5.02 \times$ age $)-309 \mathrm{~m}$.

Women $=(2.11 \times$ height $\mathrm{cm})-(2.29 \times$ weight $\mathrm{kg})-(5.78 \times$ age $)+667 \mathrm{~m}$. 
Table 10. Overview of statistical methods.

\begin{tabular}{|c|c|c|c|c|}
\hline Type of data and statistics & $\begin{array}{c}\text { Study } \\
\text { I }\end{array}$ & $\begin{array}{c}\text { Study } \\
\text { II }\end{array}$ & $\begin{array}{c}\text { Study } \\
\text { III }\end{array}$ & $\begin{array}{c}\text { Study } \\
\text { IV }\end{array}$ \\
\hline Descriptive statistics & $x$ & $x$ & $x$ & $x$ \\
\hline Mann-Whitney U & $x$ & $x$ & $x$ & $x$ \\
\hline Fisher's exact test & $x$ & $x$ & $x$ & $x$ \\
\hline Repeated measure ANOVA & $x$ & $x$ & & \\
\hline Bland-Altman plot & & & $x$ & \\
\hline Intraclass correlation & & & $x$ & \\
\hline Measurement error & & & $x$ & \\
\hline Mixed factorial ANOVA & & & & $x$ \\
\hline
\end{tabular}

\section{Ethical considerations}

The Regional Ethical Review Board of Linköping, approved the studies, Study I: Dnr99266 and Study II: Dnro2-041. Study III and IV were based on the collected results from study I and II. All included patients gave their written informed consent to participate after verbal and written information. The investigation conforms to the principles outlined in the Declaration of Helsinki. Both main studies lack a control group as exercise training is priority 3 according to The National Board of Health and Welfare guidelines (14), i.e. all patients with HF should be offered exercise training, therefore we considered it unethical to include a control group. 


\section{RESULTS}

\section{Study I}

Peripheral muscle training with resistance exercise bands in patients with chronic heart failure. Long term effects on walking distance and quality of life; a pilot study

Twenty-two patients with stable HF (3 female) were randomized to individual home-based training (HT-group), or home-based training with a group-based start-up in a hospital-setting (GT-group), with baseline testing and four follow-up occasions, every third month over 1 year.

Exercise training resulted in statistically significant increased walking distance in both groups. There were no statistically significant differences between groups on any parameters or follow-ups. The HT-group increased on average (SD) 107 (80) meters from baseline to 12 months, and the GTgroup by 100 (96) meters. Health-related quality of life, (MLHFQ and SF36), reached statistically significant improvements in both groups but at different time points. The adherence to the prescribed exercise programme was high.

\section{Study II}

Neither hospital-based nor home-based aerobic or peripheral muscle training improved walking distance or health-related quality of life during a one year follow-up in heart failure patients.

Twenty-three patients ( 5 women), were randomized to either cycling/freewalking (CEG) or peripheral muscle training (PEG). Both groups began the training period in a hospital setting for three months and thereafter the exercising continued at home for the rest of the study period.

The exercise training did not significantly improve neither the walking distance nor HRQoL, measured with 6MWT, SF-36 and MLHFQ, during the year of exercising, despite relatively high, but decreasing, adherence, either within or between the groups. 
Table 11. Study I and II.

\begin{tabular}{|c|c|c|c|c|c|c|c|c|c|}
\hline & \multicolumn{4}{|c|}{ Study I } & & \multicolumn{4}{|c|}{ Study II } \\
\hline & \multirow{2}{*}{\multicolumn{2}{|c|}{$\begin{array}{l}\text { HT-group } \\
\mathrm{N}=10\end{array}$}} & \multirow{2}{*}{\multicolumn{2}{|c|}{$\begin{array}{c}\text { PT-group } \\
\mathrm{N}=12\end{array}$}} & & \multirow{2}{*}{\multicolumn{2}{|c|}{$\begin{array}{c}\text { CEG } \\
\mathrm{N}=13\end{array}$}} & \multirow{2}{*}{\multicolumn{2}{|c|}{$\begin{array}{c}\text { PEG } \\
\mathrm{N}=10\end{array}$}} \\
\hline & & & & & & & & & \\
\hline & $\begin{array}{l}\text { Mean } \\
\text { (SD) }\end{array}$ & $\begin{array}{c}p- \\
\text { value }\end{array}$ & $\begin{array}{l}\text { Mean } \\
\text { (SD) }\end{array}$ & $\begin{array}{c}p- \\
\text { value }\end{array}$ & & $\begin{array}{l}\text { Mean } \\
\text { (SD) }\end{array}$ & $\begin{array}{c}p- \\
\text { value }\end{array}$ & $\begin{array}{l}\text { Mean } \\
\text { (SD) }\end{array}$ & $\begin{array}{c}p- \\
\text { value }\end{array}$ \\
\hline \multicolumn{10}{|c|}{ Six minute walk test, distance in meters } \\
\hline Baseline & $396(96)$ & & $392(130)$ & & Baseline & $445(80)$ & & $420(74)$ & \\
\hline 3 months & $464(118)$ & $* *$ & $490(108)$ & $* * *$ & 3 months & $457(86)$ & ns & $444(53)$ & ns \\
\hline 6 months & 469 (117) & $* * *$ & $514(97)$ & $* * *$ & 6 months & $462(95)$ & ns & $449(65)$ & ns \\
\hline 9 months & $481(105)$ & $* * *$ & $497(108)$ & $* * *$ & 9 months & 439 (99) & ns & 409 (111) & ns \\
\hline 12 months & $489(107)$ & $* * *$ & $516(119)$ & $* * *$ & 12 months & $446(97)$ & ns & $433(99)$ & ns \\
\hline
\end{tabular}

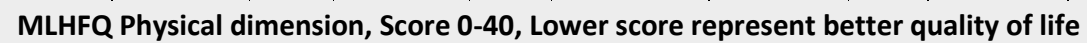

\begin{tabular}{|c|c|c|c|c|c|c|c|c|c|}
\hline Baseline & $17(12)$ & & 19 (9) & & Baseline & $13(11)$ & & $13(8)$ & \\
\hline 3 months & $14(11)$ & ns & $13(8)$ & $*$ & 3 months & $10(7)$ & ns & $12(8)$ & ns \\
\hline 6 months & $12(12)$ & $*$ & $13(9)$ & $*$ & 6 months & $8(9)$ & ns & $14(8)$ & ns \\
\hline 9 months & 11 (11) & $*$ & $13(10)$ & $*$ & 9 months & $9(10)$ & ns & 16 (11) & ns \\
\hline 12 months & $13(12)$ & ns & $12(5)$ & $* *$ & 12 months & $9(9)$ & ns & $14(10)$ & ns \\
\hline
\end{tabular}

MLHFQ Emotional dimension, Score 0-20, Lower score represent better quality of life

\begin{tabular}{llll|llllll}
\hline Baseline & $9(8)$ & & $10(4)$ & & Baseline & $6(6)$ & & $6(6)$ & \\
3 months & $8(6)$ & ns & $6(4)$ & $*$ & 3 months & $6(6)$ & ns & $5(6)$ & ns \\
6 months & $7(6)$ & ns & $7(4)$ & ns & 6 months & $5(5)$ & ns & $7(5)$ & ns \\
9 months & $7(7)$ & ns & $7(6)$ & ns & 9 months & $6(5)$ & ns & $7(6)$ & ns \\
12 months & $7(6)$ & ns & $5(5)$ & $* *$ & 12 months & $6(6)$ & ns & $8(6)$ & ns \\
\hline
\end{tabular}

\begin{tabular}{lllll|llllll}
\hline \multicolumn{8}{c}{ SF-36 - PCS, Score 0-100, Higher score represent better quality of life } \\
\hline Baseline & $54(26)$ & & $45(21)$ & & Baseline & $57(24)$ & & $57(19)$ & \\
3 months & $57(26)$ & ns & $56(15)$ & $*$ & 3 months & $57(26)$ & ns & $60(16)$ & ns \\
6 months & $60(28)$ & ns & $62(14)$ & $* *$ & 6 months & $63(24)$ & ns & $54(24)$ & ns \\
9 months & $64(25)$ & ns & $56(21)$ & $*$ & 9 months & $60(24)$ & ns & $48(17)$ & ns \\
12 months & $65(29)$ & $*$ & $57(16)$ & $*$ & 12 months & $58(21)$ & ns & $55(21)$ & ns \\
\hline
\end{tabular}

SF-36 - MCS, Score 0-100, Higher score represent better quality of life

\begin{tabular}{lllll|lllll}
\hline Baseline & $58(24)$ & & $50(21)$ & & Baseline & $68(25)$ & & $66(20)$ & \\
3 months & $62(22)$ & ns & $60(16)$ & $*$ & 3 months & $63(25)$ & ns & $71(12)$ & $n s$ \\
6 months & $66(28)$ & ns & $65(15)$ & $* *$ & 6 months & $70(22)$ & $n s$ & $64(23)$ & $n s$ \\
9 months & $69(25)$ & $*$ & $63(21)$ & $* *$ & 9 months & $65(24)$ & $n s$ & $60(18)$ & $n s$ \\
12 months & $70(27)$ & $*$ & $62(16)$ & $*$ & 12 months & $63(22)$ & ns & $63(21)$ & $n s$ \\
\hline
\end{tabular}

HT-group, home training group; PT-group, physiotherapist-led group; CEG, cycling exercise group; PEG, peripheral exercise group; MLHFQ, Minnesota Living with Heart Failure Questionnaire; SF-36; Short Form 36 items; PCS, physical component summary score; MCS, mental component summary score 


\section{Study III}

Test-retest reliability of six-minute walk tests over a one year period in patients with chronic heart failure

Forty-six patients ( 9 female) performed the 6MWT every third month for one year, in total 198 duplicated test (totally 396 6MWTs).

An improvement of 8.7 meters (1.9\%) was seen in the second 6MWT calculated on all performed follow-ups. This was considered not to be of clinical significance. The average measurement error $\left(\mathrm{S}_{\text {method }}\right)$ ranged from 2.4 to $3.9 \%$ over the study period, and the relative test-retest reliability calculated as ICC was mean 0.98 (CI95\% 0.96-0.99). The variation over time was not statistically significant.

\section{Study IV}

Six minute walk test versus health-related quality of life in patients with chronic heart failure

Forty-six patients (37 men and 9 female) performed 6MWT and administered the SF-36 and the MLHFQ on five occasions.

Patients were divided into two groups, below and above the median walked distance of $92 \%$ corresponding to the predicted value. Pred $<92 \%$; $403 \pm 77 \mathrm{~m}(76 \pm 13 \%$ of the predicted value) and, Pred $\geq 92 \% ; 517 \pm 67 \mathrm{~m}$ (104 $\pm 10 \%$ of the predicted value).

Patients with a walking distance lower than median $<92 \%$ of walking distance experienced a lower HRQoL than the higher performing half of the cohort, walking distance $>92 \%$, in four dimensions of the SF-36 (PR, $\mathrm{RP}, \mathrm{GH}$ and RE) and both the physical and mental components score. No association, in either group, was seen between walked distance and MLHFQ. 
Figure 4. Six minute walk test, study I versus study II.

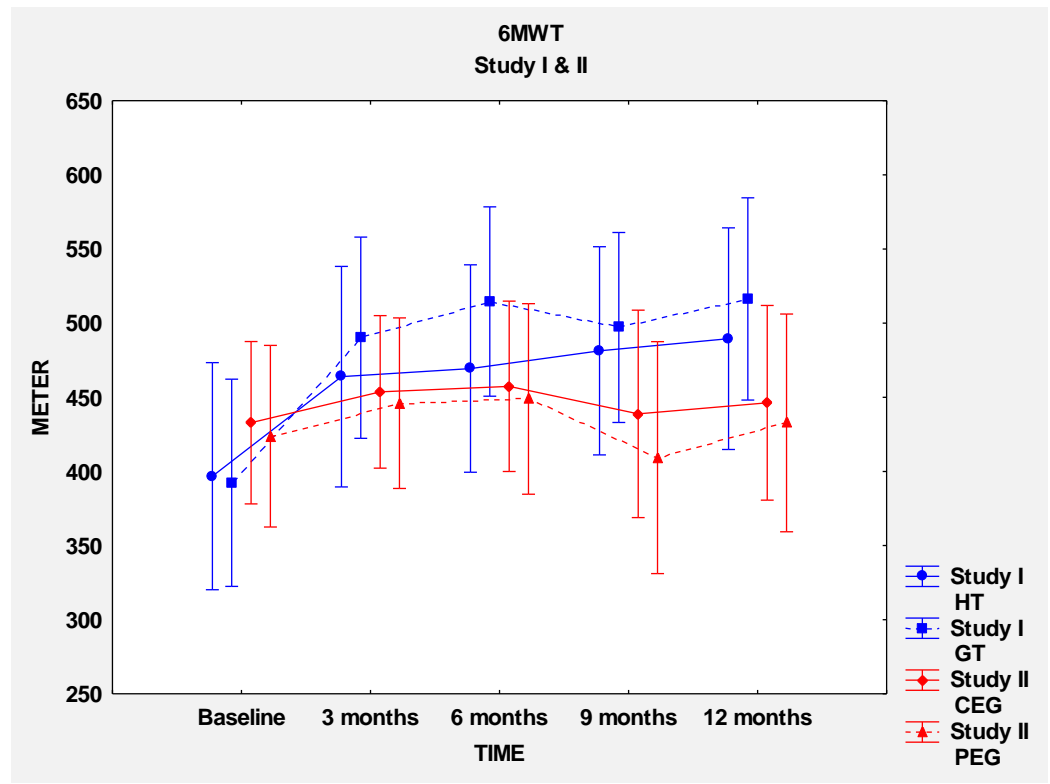

Figure 5. Adherence to prescribed exercise, study I versus study II.

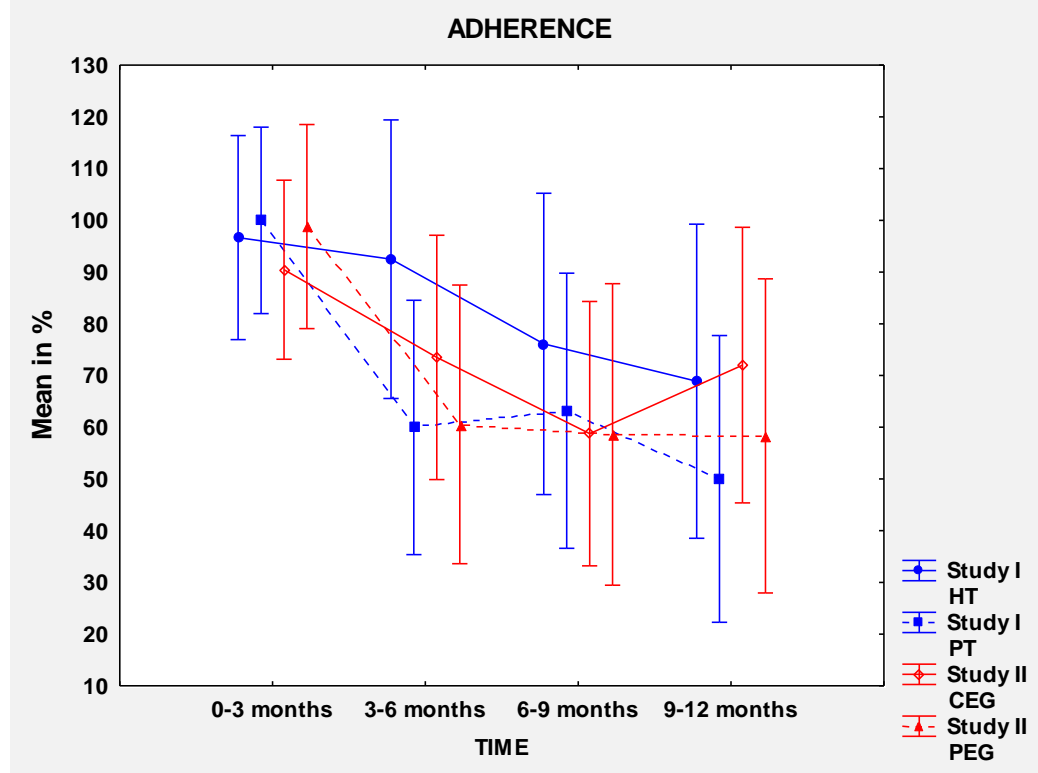




\section{DISCUSSION}

Historically, exercise training in patients with HF was proscribed until the late 1980s, when Sullivan et al. (92), for the first time, showed that exercise training for 12 weeks improved exercise tolerance. This study is a mainstay in research by changing the scientific approach to the relationship between $\mathrm{HF}$ and exercising.

The research in this thesis aims to evaluate and further develop exercise training and testing to make it more accessible and userfriendly for both clinical practice and heart failure patients.

Since the 1980s, numerous studies have shown positive effects of exercise training in heart failure (93) and it has also become a class IA recommendation in both European and American guidelines $(11,12)$.

Despite this, only a small portion of patients with HF receives a customized individually based exercise program (10). This is about to change in Europe (15).

\section{Exercise training}

Patients with HF often experience poor physical function and impaired quality of life with low daily physical activity and immobilization as a result (94).

Promoting enhanced physical activity and physical exercise is important to gain benefits such as reduced mortality, reduced hospitalization, increased physical function and improved HRQoL (11-13). However, some patients with $\mathrm{HF}$ are difficult to engage in exercise training $(39,45,71)$.

An exercise training programme in patients with HF should include both aerobic and resistance elements $(13,46)$. Since it is difficult for some patients to participate in cardiac rehabilitation in a hospital-setting we aimed to evaluate a training programme that would suite most patients. Moreover, participation in a supervised programme in a hospital-setting lasts for a limited period which means that patients with HF must find 
another exercise setting after discharge from hospital based rehabilitation and training.

In study I, we evaluated a PMT programme in both a hospital- and a homebased setting. In both settings the patients increased their walking distance after three months of exercising and maintained the improvement over the 1-year study period, Figure 4. In this study, the walked distance was just below 400 meters in both groups at baseline, which is in line with similar studies (95). They increased their walked distance by about 100 meters, which was statistically significant, and more than average in similar studies (95-97). There were no significant differences regarding training effects between the 2 groups that received an initial period of hospital-based training or not. We could not repeat the improvements in study II, despite the similar approach, Figure 4. Nor was there any cardiac event reported, in study I and II, neither in the hospital-setting nor at home.

The fact that there was no significant change in either breathlessness according to the CR-10 scale, Borg's RPE or heart rate despite the increased walking distance, indicates that patients in study I had increased their maximum oxygen consumption. Although an increase of central circulatory capacity, probably based on a general increase in physical activity, cannot be excluded, a peripheral adaptation including e.g. improved muscle metabolism and capillarization, and thereby an increased maximal arteriovenous oxygen difference is likely to have contributed to the improvement (32).

The probable changes in the submaximal muscle endurance, obtained by low-intensive resistance training, may reflect the importance from the patient's perspective since most daily activities are done at submaximal force levels rather than maximal force production, gained by high-intensive strength training (98). This would favour a PMT programme.

To implement also an aerobic element of exercise, to reach exercise recommendations (11-13), we compared PMT with an aerobic training in study II. The mode of aerobic training was interval training on a bicycle ergometer in a hospital setting for 3 months, followed by free-walking in the home-based setting, as an attempt to find an accepted mode of aerobic exercising at home. This was compared with the PMT, also in hospital- and home-based setting in the same timeframe. The advantage of ergometer cycling is the possibility to measure and set the load individually, at for example $80 \%$ of $\mathrm{HR}$ which is in line with aerobic exercise recommendations $(13,46)$. It is harder to measure and set the load with 
elastic bands, and the knowledge about the elastic bands properties is important to achieve the right load. This we could not measure. But the intensity can be adjusted by using the RPE scale, a useful way for patients to achieve the prescribed RPE when exercising (13), both in a hospital- and home based-setting. In study II, walking distance did not increase over the study period in either of the 2 groups.

It should however be borne in mind that HF has a progressive development (25) and that with age, the predicted walking distance and work capacity "normally" decreases $(75,99)$. In line with study II, earlier studies have shown none or poor improvement by an exercise programme in $\mathrm{HF}$ patients $(100,101)$. A lack of deterioration can thereby be interpreted as an improvement. This, and possible reasons for the different results in study I and study II, has been discussed more in-depth in Paper II.

Briefly, the mean age of the patients was higher in study II and despite this their 6-min walking distance was longer. Thus the potential to improve their physical function further may have been lower. One may also speculate whether one or two so called non-responders to training (102) may have participated in study II and reduced the group mean results. However, this was not the case since the results of the participating subjects were more homogenous.

Both modes of exercising were well tolerated and no cardiac events were reported.

\section{Functional testing}

Since HF is a syndrome with a progressive development and a poor longterm prognosis (18), it is valuable to detect changes over time (89).

CPET is the "gold standard" in measuring exercise capacity $(103,104)$ and probably the most frequently used exercise test in patients with HF; it is often recommended before starting cardiac rehabilitation $(44,105)$. Most patients will not undergo CPET before cardiac rehabilitation since the access to CPET is limited (106), e.g. in smaller hospitals or primary care. This may delay cardiac rehabilitation, and even lead to immobilization if there is no acceptable alternative test method before starting the rehabilitation period. In the absence of CPET, the 6MWT is recommended in different guidelines and reviews since it is a common functional test (39, 107, 108). It has also been suggested that 6MWT can predict VO2 (109) using the following equation (110):

Mean Peak VO2 $(\mathrm{ml} / \mathrm{kg} / \mathrm{min})=(4.948+0.023) *$ Mean 6 MWD (meters) 
There is a learning effect when the 6MWT is performed twice or more (111). Studies have shown that the walked distance has a tendency to increase with repeated 6MWT, indicating a learning effect by familiarization. The amount of learning effect differs between studies $(112,113)$. Singh et al. (114) showed a learning effect of 26 meters, but these pooled data were in patients with lung diseases, not studied in patients with HF. The learning effect has been described as an increase between 2 tests but there might also be a "negative learning effect". If the first walk test is too physically demanding and feels overwhelming, this might affect the willingness to perform a second walk test (115).

In study III, we showed that the test-retest reliability was excellent over a one year period; this is important if measurements should be continued over time. The learning effect was 9 meters; this reached statistical significance but we interpreted that 9 meters was too small for a clinical significance. We interpret our results as in a clinic practice were it is enough to perform a single $6 \mathrm{MWT}$, but in a study it could be valuable with more than a single test.

In both study I and II the patients performed two 6MWT with 45 minutes rest in between, at all test occasions, baseline and during follow-up. These data were in study III used to explore if it is necessary to perform the 6MWT twice. Since most of the patients with HF suffer from low physical function, it is inappropriate that the patients perform the 6MWT twice if it does not add any further information.

According to ATS (73) the straight surface at $6 \mathrm{MWT}$ can be 50-164 feet ( $\sim 15-50$ meters) with no significant effect on the walked distance. ATS recommend using a 30 meter flat corridor. In both study I and II the walking track was 80 meters long, which had the advantage of minimizing the number of turns. A potential disadvantage is that the track may feel overwhelming if the patient is in poor physical shape, but our patients generally had a longer walking distance, and this was not perceived as a problem.

The 6MWT can be used more frequently than other types of exercise testing because it is quick and easy, requires minimal equipment, and is well tolerated by patients. It is, however, still important to standardize the execution of the test, for patients with HF.

Opinions regarding encouragement during the 6MWT are divided. Encouragement is recommended but not imperative $(73,114,116)$, e.g. the conclusion, in a frequently referenced study by Guyatt, (117) "there is no compelling reason to either give or not give encouragement, so long as tests 
are conducted in a consistent manner". The study of Guyatt (117), enrolled 43 patients, 25 in the respiratory group and 18 in the cardiac group.

Neither in study I or II was encouragement given, since external pacing during the test situation, e.g. impaired hearing, may affect the test protocol (116).

\section{Health-related quality of life}

Health-related quality of life is impaired in patients with $\operatorname{HF}(67,68)$, however, the HRQoL can increase in HF patients participating in an exercise training programme (58).

We evaluated the quality of life status before and after the exercise interventions in study I and II. The HRQoL did increase significantly in study I but not in study II despite similar training interventions. Whether this was coupled to the improved physical function, measured as improved 6MWD in study I is possible but not proven. The small number of participants in both studies may however also have contributed to the divergent results.

To shed more light on this, we decided to investigate the connection between perceived HRQoL and walking distance in study IV. Our hypothesis was that a shorter walked distance is related to a poorer HRQoL. This hypothesis could not fully be confirmed. Study IV showed that the relationship between HRQoL and walked distance was poor.

The median of walked distance of all patients was high, 92\% of predicted value for healthy individuals, taking gender, age, height and weight into account. The score of the SF-36 in our patients was approximately $20 \mathrm{p}$ lower than the SF-36 in a normal population (79). The patients with a lower walked distance than median had lower HRQoL by several dimensions of the SF- 36. No such relationship was seen in MLHFQ scores. This might reflect that our patients, stable on medical treatment, were not overtly symptomatic with classical heart failure symptoms, but still suffered some limitation in their daily life activities.

\section{Adherence and barriers}

It has been reported that patients with heart failure have difficulty following recommendations for exercise. Evangelista et al. showed that $61 \%$ of patients with $\mathrm{HF}$ estimated adhering to an exercise recommendation harder than to other recommendations, e.g. medicine, dietary. Barriers for participating in cardiac rehabilitation and exercise 
training could be lack of motivation, lack of energy and presence of symptoms $(31,71,72,118)$.

It is difficult to measure adherence to home-based training according to no consensus in measurement $(119,120)$ but still and surprisingly there seems to be a tendency towards higher adherence to exercise in a home-based setting rather than in a hospital/center-based setting $(120,121)$.

In study I and II, the patients kept a logbook over exercise sessions, time and RPE per session and we noticed the difficulty in measuring adherence. Despite detailed oral and written information about completion of the logbook, patients interpreted this differently and several patients had also counted time for activities such as housekeeping. However, this time was excluded from the analysis.

Many patients are unable to participate in a training programme in a hospital-setting because they live far away, have problems of transportation or cannot afford to pay the fee for training at hospital (122, 123). For these patients a home-based exercise training programme could be an alternative.

In study I, the adherence was good, according to the logbook, in both intervention groups. In the group which started exercising under supervision for 3 months, the adherence decreased over the period. The home-based training group exercised 3 times per week over the study period, but they also lost in adherence over time. Supervised exercise in the hospital-setting was twice per week and after discharge the training sessions were increased to 3 times per week. However, the group continued to exercise twice a week, probably because of the habit to do so. This was not the case in study II; the adherence was good in both intervention groups but decreased over time as well. The adherence tends to decrease over time in trials as well as in real life $(71,118)$.

According to long-term low adherence and barriers to exercise training, like lack of time and energy (71) it seems necessary to monitor and optimize exercise modalities to increase adherence and overcome barriers in patients with HF.

More importantly, an item which has caught our attention in recent years, is that elderly patients show low confidence to exercise (124-126). Confidence to exercise is an individual's belief in their own ability to initiate or maintain regular physical activity (125). Many older patients have no experience of exercising and are worried about not being able to cope with the exercise programme, which may reflect a low confidence to exercise. It is important that intensity of the exercise programme is challenging but not 
overwhelming; the patient must experience a sense in success of mastering the exercise and thus increase their confidence to exercise. It seems more likely that we accomplished that in study I than in study II.

\section{Home- and hospital setting}

Most previous studies have evaluated exercise training programs in a hospital-setting, for a shorter limited period (50, 84, 127-130). It seems like there is a quite rapid deterioration after finished exercise training in a hospital-setting $(131,132)$. Only a few studies with long-term follow-up for a year or longer are reported (133-135).

Home-based training programs have been reported and have focused on walking or bicycling (123, 133, 135-137). Studies using center-based training followed by a home-based training program compared to a solely home-based training program are rare $(135,138,139)$. In addition, only a few long-term studies of home-based peripheral muscle training have been reported $(123,135,137)$.

In study I, the patients gained walked distance and increased HRQoL and maintained this over the study period regardless of introductory period.

In a meta-analysis by Buckingham et al. based on a Cochrane report, it was concluded that both home-based and hospital/center-based cardiac rehabilitation had same benefits in patients with HF (120, 140), and that patient's choice of exercise setting according to their preferences may increase adherence $(120,121)$.

According to this, home-based training seems to be a good alternative to supervised training after discharge from cardiac rehabilitation, or solely if wanted, according to patients' choice.

\section{Life-long training programme}

A long-term exercise program $(141,142)$ can be difficult for patients with HF when symptoms of dyspnea and fatigue occur already with light physical/daily activity and therefore may limit the patients' willingness to exercise (93).

In recent years, attempts to streamline exercise training with shorter bouts of exercise have been made, e.g. aerobic interval training (AIT) with higher intensity (143) or low-volume time-efficient resistance training (96). Wisloff et al. (143) showed that AIT on treadmill with as high as $95 \%$ of peak HR in older patients with HF $(76.5 \pm 9$ years) was well tolerated compared with moderate continuous walking at an intensity of $70-75 \%$ of peak HR. The increase in $\mathrm{VO}_{2}$ was larger in the AIT group (46\%) than in 
the continuous walking group (14\%). Both groups also increased HRQoL. Munch et al. (96) on the other hand, had a different approach, comparing moderate continuous cycling for 45 minutes ( $75 \%$ of Watt ${ }_{\text {peak }}$ ), with lowvolume resistance training for 25 minutes ( 4 sets, 1 set at $25 \%$ and 3 sets at $40 \%$ of 1RM. Exercise time include warm-up period. Both improved equally regarding $\mathrm{VO}_{2}$, Watt ${ }_{\text {peak, }}$ 6MWD and HRQoL. However, the patients in this study were younger $61 \pm 3$ years. Aerobic interval training has been shown to be more efficient than aerobic continuous training for increasing $\mathrm{VO}_{2}(60)$.

Shah et al. (144) showed the impact of holiday winter time, like Christmas, was associated with increased HF events directly after the holiday, associated with i.a. reduced exercise. Another study (145) confirmed the seasonal variation with lower physical activity during the winter period among patients with HF. During winter time it can be hard with a freewalking exercise programme, due to e.g. risk of fall; with a PMT programme it is easy to continue exercising.

We think that we have found an exercise mode (PMT with elastic bands) that patients are able to adhere to over seasons and holidays. Exercising with elastic bands is easy and can be adjusted after degree of symptoms; when feeling better the patients can tighten the elastic bands, and with feeling worse can slacken the elastic bands and can still estimate perceived exertion on the RPE scale.

Finally, the selection of the exercise modality should take into account the patient's age, concomitant diseases, leisure and working habits, preferences and abilities, logistical restraints, and the availability of exercise facilities and equipment $(39,40)$. An exercise modality such as walking and resistance training with body weight or elastic bands, a longterm exercise training to be performed at home, for older patients with HF, might be recommended.

Based on our results, we suggest that peripheral muscle training could promote improved daily living, such as quality of life and walking distance over time.

\section{Limitations}

There is a difficulty in attracting women to participate in studies. This might be attributed to the fact that women are older when having the diagnosis of heart failure, and then more often with preserved EF. 
The lack of a control group is based on the national and international recommendation for physical activity, partly for healthy individuals but especially for patients with HF.

There is limited evidence of the benefits of exercise in patients with HF and preserved EF and our results cannot be generalized to that population. 


\section{CONCLUSIONS}

Peripheral muscle training resulted in improved physical function and health-related quality of life in one study and absence of deterioration in another, indicating that peripheral muscle training is useful and effective in the training of heart failure patients.

The effects over a one-year follow-up were similar whether starting with a 3-months hospital-based training period or not.

When comparing one group of heart failure patients having PMT and another performing aerobic exercise, the outcome in terms of walking distance and health-related quality of life was equal.

Duplicating the 6-minute walk test with 45 minutes rest in between gave a slightly, albeit significantly longer walking distance at the second test, a clinically unimportant difference of only 9 meters (2\%). This was the case also at follow-up every $3^{\text {rd }}$ month over the one year follow-up.

A shorter walking distance was related to an inferior rating of healthrelated quality of life evaluated by the generic instrument SF-36 but to a much lesser degree by the disease-specific Minnesota Living with Heart Failure Questionnaire.

\section{Clinical implications}

Home-based training is a possible alternative to hospital-based and can, with regular follow-up, be the solution of the need for long-term training in these patients.

Peripheral muscle training is effective and useful in heart failure patients.

Patients should thus be offered to choose exercise modality, and hospital/center based or home-based training, based on their preferences.

Six minute walk tests need not to be duplicated in clinical practise. 
For the evaluation of severity of heart failure symptoms and effects of treatment it is important to be aware that the different evaluation tools measure different aspects of the spectrum of functional impairment.

\section{Future research and development}

There is a need for strategies to get patients with heart failure to participate in cardiac rehabilitation and to overcome barriers for participation.

Solutions for increasing adherence to exercise, such as smartphone applications, websites, validated logbook should be developed and evaluated.

The lack of opportunities for prolonging exercise training after discharge from cardiac rehabilitation, especially for older patients should be addressed. Involving of community services, and involving sports clubs to establish special "heart patient visits" with an exercise instructor present, are some examples. 


\section{ACKNOWLEDGEMENT}

I wish to express my sincere gratitude to everyone who has contributed to my work. In particular I would like to thank:

All patients who willingly and with great enthusiasm participated in the studies and made it possible to complete this thesis.

Lars Brudin - my co-supervisor and co-author, who has been involved from the start. For generosity and sharing his enormous knowledge and guidance through the tangled forest named statistics, for all help with preparation and completing the studies and this thesis.

Eva Nylander - my head supervisor and co-author, who joined later on with a lot of commitment, positive support, encouragement and guidance through the "research jungle", preparation of manuscripts and finally the completion of this thesis.

Åsa Cider - my co-supervisor and co-author, for constructive criticism during the preparation of the manuscripts and the completion of the thesis.

Finn Landgren - my first tutor, whom I first was terrified of, but still asked to be my supervisor in my C-essay. For all rewarding discussions, for sharing great knowledge and for encouragement and believing in me. Unfortunately he passed away before this thesis completion and I miss him a lot.

DeeDee Lindh, my American former colleague and friend, for linguistic advice and revisions.

My warmest thanks to Region Kalmar County and the Research section for financial support.

Magnus Hellström, head of Rehab Söder, and Marie Simonsson head of Dept. of Occupational and Physiotherapy, for providing me the opportunity to accomplish the training sessions, follow-ups and completion of this thesis.

Thanks to colleagues and friends at the Departments of Occupational and Physiotherapy and Cardiology at Kalmar County Hospital.

Special thanks to Anna Isgren Sjösten- My former colleague whom performed all the tests. 
Department of Health, Medicine and Caring Sciences for having me as a PhD student, for many, many years.

Gunilla Ekeroth - heart failure nurse at the cardiology unit at Kalmar County Hospital, for help finding eligible patients for inclusion in the studies.

To the staff of Department of Physiology, Kalmar County Hospital, who performed the bicycle exercise tests and ultrasound examinations of the heart.

My fellow $\mathrm{PhD}$ (students) in physiotherapy - Anneli Thelandersson (PhD 2016), Maria Borland (PhD 2018), Linda Ashman Kröönström (PhD 2020), Stefan Lundqvist (PhD 2020) - for discussions and support. I am the last one to go - Mission completed!

Solbritt Andersson - librarian at the university library at Linneaus University, for help with EndNote's unruly reference management software.

All Stars Team - Suzanne Petersson and Susanne Ekdahl - for friendship, encouragement and many inspiring discussions about research and other things.

Champagneflickorna - Camilla Berntsson and Marie Stridh - for all glasses of champagne we have 'tasted' (so far...), all missteps during dance classes and all the flea markets we have been looking through. For encouragement, even though you don't understand what I'm doing, and recreation with many laughs and gossiping and all discussions about anything but research and science.

My family, Janne - my dearest husband, the love of my life, for understanding, support and love. With love to my stepchildren Rebecca and Hampus with families. Birgitta - my mother and biggest fan.

Johan - my big brother and best friend until he died too early in Cystic Fibrosis. It is your fault that I became a physiotherapist! I still miss you every day! 


\section{REFERENCES}

1. Caspersen CJ, Powell KE, Christenson GM. Physical activity, exercise, and physical fitness: definitions and distinctions for health-related research. Public Health Rep. 1985;100(2):126-31.

2. Arena R, Myers J, Williams MA, Gulati M, Kligfield P, Balady GJ, et al. Assessment of functional capacity in clinical and research settings: a scientific statement from the American Heart Association Committee on Exercise, Rehabilitation, and Prevention of the Council on Clinical Cardiology and the Council on Cardiovascular Nursing. Circulation. 2007;116(3):329-43.

3. Del Buono MG, Arena R, Borlaug BA, Carbone S, Canada JM, Kirkman DL, et al. Exercise Intolerance in Patients With Heart Failure: JACC State-of-the-Art Review. J Am Coll Cardiol. 2019;73(17):2209-25.

4. World Health Organization. Global Recommendations on Physical Activity for Health. Geneva, World Health Organization, 2010 Retrieved from WHO website:

https://www.who.int/dietphysicalactivity/publications/97892415999 79/en/

5. Garber CE, Blissmer B, Deschenes MR, Franklin BA, Lamonte MJ, Lee IM, et al. American College of Sports Medicine position stand. Quantity and quality of exercise for developing and maintaining cardiorespiratory, musculoskeletal, and neuromotor fitness in apparently healthy adults: guidance for prescribing exercise. Med Sci Sports Exerc. 2011;43(7):1334-59.

6. WHOQoL. Measuring quality of life: The World Health Organization quality of life instruments (the WHOQOL-100 and the WHOQOLBREF). Geneva, World Health Organization, 1997. Retrieved from WHO website: https://www.who.int/toolkits/whoqol

7. Kenney WL, Wilmore JH, Costill DL. Physiology of sport and exercise with web study guide: Human kinetics; 2019.

8. WHO. Guidelines on physical activity and sedentary behaviour 2020. Geneva, World Health Organization, 2020. Retrieved from WHO website: https://www.who.int/publications/i/item/9789240015128

9. Morris JN. Exercise in the prevention of coronary heart disease: today's best buy in public health. Med Sci Sports Exerc. 1994;26(7):807-14.

10. Bjarnason-Wehrens B, McGee H, Zwisler AD, Piepoli MF, Benzer W, Schmid JP, et al. Cardiac rehabilitation in Europe: results from the European Cardiac Rehabilitation Inventory Survey. Eur J Cardiovasc Prev Rehabil. 2010;17(4):410-8.

11. Ponikowski P, Voors AA, Anker SD, Bueno H, Cleland JG, Coats AJ, et al. 2016 ESC Guidelines for the diagnosis and treatment of acute and chronic heart failure: The Task Force for the diagnosis and treatment 
of acute and chronic heart failure of the European Society of Cardiology (ESC). Developed with the special contribution of the Heart Failure Association (HFA) of the ESC. Eur J Heart Fail. 2016;18(8):891-975.

12. Yancy CW, Jessup M, Bozkurt B, Butler J, Casey DE, Jr., Colvin MM, et al. 2017 ACC/AHA/HFSA Focused Update of the 2013 ACCF/AHA Guideline for the Management of Heart Failure: A Report of the American College of Cardiology/American Heart Association Task Force on Clinical Practice Guidelines and the Heart Failure Society of America. Circulation. 2017;136(6):e137-e61.

13. Pelliccia A, Sharma S, Gati S, Bäck M, Börjesson M, Caselli S, et al. 2020 ESC Guidelines on sports cardiology and exercise in patients with cardiovascular disease. Eur Heart J. 2020.

14. Nationella riktlinjer för hjärtsjukvård 2015 : stöd för styrning och ledning. Stockholm: Socialstyrelsen; 2015.

15. Piepoli MF, Binno S, Corrà U, Seferovic P, Conraads V, Jaarsma T, et al. ExtraHF survey: the first European survey on implementation of exercise training in heart failure patients. Eur $\mathrm{J}$ Heart Fail. 2015;17(6):631-8.

16. Deka P, Pozehl B, Williams MA, Yates B. Adherence to recommended exercise guidelines in patients with heart failure. Heart Fail Rev. 2017;22(1):41-53.

17. McMurray JJ, Adamopoulos S, Anker SD, Auricchio A, Bohm M, Dickstein K, et al. ESC guidelines for the diagnosis and treatment of acute and chronic heart failure 2012: The Task Force for the Diagnosis and Treatment of Acute and Chronic Heart Failure 2012 of the European Society of Cardiology. Developed in collaboration with the Heart Failure Association (HFA) of the ESC. Eur J Heart Fail. 2012;14(8):803-69.

18. Mosterd A, Hoes AW. Clinical epidemiology of heart failure. Heart. 2007;93(9):1137-46.

19. Lindmark K, Boman K, Olofsson M, Törnblom M, Levine A, CasteloBranco A, et al. Epidemiology of heart failure and trends in diagnostic work-up: a retrospective, population-based cohort study in Sweden. Clin Epidemiol. 2019;11:231-44.

20. Roger VL. Epidemiology of heart failure. Circ Res. 2013;113(6):646-59.

21. Zarrinkoub R, Wettermark B, Wandell P, Mejhert M, Szulkin R, Ljunggren $\mathrm{G}$, et al. The epidemiology of heart failure, based on data for 2.1 million inhabitants in Sweden. Eur J Heart Fail. 2013;15(9):9951002.

22. McMurray JJ, Stewart S. Epidemiology, aetiology, and prognosis of heart failure. Heart. 2000;83(5):596-602.

23. The survival of patients with heart failure with preserved or reduced left ventricular ejection fraction: an individual patient data metaanalysis. Eur Heart J. 2012;33(14):1750-7.

24. Aurigemma GP, Gaasch WH. Clinical practice. Diastolic heart failure. N Engl J Med. 2004;351(11):1097-105. 
25. McMurray JJ. Clinical practice. Systolic heart failure. N Engl J Med. 2010;362(3):228-38.

26. Persson J, Stagmo M. Perssons Kardiologi-Hjärtsjukdomar hos vuxna (7: e upplagan). Lund: Studentlitteratur AB. 2014.

27. Franciosa JA, Park M, Levine TB. Lack of correlation between exercise capacity and indexes of resting left ventricular performance in heart failure. Am J Cardiol. 1981;47(1):33-9.

28. Piepoli MF, Crisafulli A. Pathophysiology of human heart failure: importance of skeletal muscle myopathy and reflexes. Exp Physiol. 2014;99(4):609-15.

29. Andronic AA, Mihaila S, Cinteza M. Heart Failure with Mid-Range Ejection Fraction - a New Category of Heart Failure or Still a Gray Zone. Maedica. 2016;11(4):320-4.

30. Yancy CW, Jessup M, Bozkurt B, Butler J, Casey DE, Jr., Drazner MH, et al. 2013 ACCF/AHA guideline for the management of heart failure: a report of the American College of Cardiology Foundation/American Heart Association Task Force on Practice Guidelines. J Am Coll Cardiol. 2013;62(16):e147-239.

31. Morris JH, Chen L. Exercise Training and Heart Failure: A Review of the Literature. Card Fail Rev. 2019;5(1):57-61.

32. Piepoli MF, Coats AJ. The 'skeletal muscle hypothesis in heart failure' revised. Eur Heart J. 2013;34(7):486-8.

33. Marvin H. Diseases of the Heart and Blood Vessels: Nomenclature and Criteria for Diagnosis. Arch Intern Med. 1964;113(6):906-7.

34. Paneroni M, Pasini E, Comini L, Vitacca M, Schena F, Scalvini S, et al. Skeletal Muscle Myopathy in Heart Failure: the Role of Ejection Fraction. Curr Cardiol Rep. 2018;20(11):116.

35. Piepoli MF, Kaczmarek A, Francis DP, Davies LC, Rauchhaus M, Jankowska EA, et al. Reduced peripheral skeletal muscle mass and abnormal reflex physiology in chronic heart failure. Circulation. 2006;114(2):126-34.

36. Belli JF, Bacal F, Bocchi EA, Guimaraes GV. Ergoreflex activity in heart failure. Arq Bras Cardiol. 2011;97(2):171-8.

37. Conraads VM, Van Craenenbroeck EM, De Maeyer C, Van Berendoncks AM, Beckers PJ, Vrints CJ. Unraveling new mechanisms of exercise intolerance in chronic heart failure: role of exercise training. Heart Fail Rev. 2013;18(1):65-77.

38. Piepoli MF. Exercise training in heart failure. Curr Heart Fail Rep. 2006;3(4):189-96.

39. Piepoli MF, Conraads V, Corra U, Dickstein K, Francis DP, Jaarsma T, et al. Exercise training in heart failure: from theory to practice. A consensus document of the Heart Failure Association and the European Association for Cardiovascular Prevention and Rehabilitation. Eur J Heart Fail. 2011;13(4):347-57.

40. Niebauer J. Cardiac rehabilitation manual: Springer; 2017.

41. Balady GJ, Williams MA, Ades PA, Bittner V, Comoss P, Foody JM, et al. Core components of cardiac rehabilitation/secondary prevention 
programs: 2007 update: a scientific statement from the American Heart Association Exercise, Cardiac Rehabilitation, and Prevention Committee, the Council on Clinical Cardiology; the Councils on Cardiovascular Nursing, Epidemiology and Prevention, and Nutrition, Physical Activity, and Metabolism; and the American Association of Cardiovascular and Pulmonary Rehabilitation. Circulation. 2007;115(20):2675-82.

42. Rossignol P, Hernandez AF, Solomon SD, Zannad F. Heart failure drug treatment. Lancet. 2019;393(10175):1034-44.

43. Berliner D, Hallbaum M, Bauersachs J. Current drug therapy for heart failure with reduced ejection fraction. Herz. 2018;43(5):383-91.

44. Corra U, Piepoli MF, Carre F, Heuschmann P, Hoffmann U, Verschuren $M$, et al. Secondary prevention through cardiac rehabilitation: physical activity counselling and exercise training: key components of the position paper from the Cardiac Rehabilitation Section of the European Association of Cardiovascular Prevention and Rehabilitation. Eur Heart J. 2010;31(16):1967-74.

45. Dontje ML, van der Wal MH, Stolk RP, Brügemann J, Jaarsma T, Wijtvliet PE, et al. Daily physical activity in stable heart failure patients. J Cardiovasc Nurs. 2014;29(3):218-26.

46. American College of Sports Medicine, ACoSM. ACSM's guidelines for exercise testing and prescription. Tenth ed: Lippincott Williams \& Wilkins; 2013.

47. Pattyn N, Beulque R, Cornelissen V. Aerobic Interval vs. Continuous Training in Patients with Coronary Artery Disease or Heart Failure: An Updated Systematic Review and Meta-Analysis with a Focus on Secondary Outcomes. Sports Med. 2018;48(5):1189-205.

48. Fleck SJ, Kraemer W. Designing resistance training programs, 4E: Human Kinetics; 2014.

49. Bjarnason-Wehrens B. Recommendations for resistance exercise in cardiac rehabilitation: Do they need reconsideration? European journal of preventive cardiology. 2019;26(14):1479-82.

50. Cider A, Tygesson H, Hedberg M, Seligman L, Wennerblom B, Sunnerhagen KS. Peripheral muscle training in patients with clinical signs of heart failure. Scand J Rehabil Med. 1997;29(2):121-7.

51. Gaffney FA, Grimby G, Danneskiold-Samsoe B, Halskov O. Adaptation to peripheral muscle training. Scand J Rehabil Med. 1981;13(1):11-6.

52. Delagardelle C, Feiereisen P, Krecke R, Essamri B, Beissel J. Objective effects of a 6 months' endurance and strength training program in outpatients with congestive heart failure. Med Sci Sports Exerc. 1999;31(8):1102-7.

53. Cattadori G, Segurini C, Picozzi A, Padeletti L, Anzà C. Exercise and heart failure: an update. ESC heart failure. 2018;5(2):222-32.

54. Palmer K, Bowles K-A, Paton M, Jepson M, Lane R. Chronic heart failure and exercise rehabilitation: a systematic review and metaanalysis. Arch Phys Med Rehabil. 2018;99(12):2570-82. 
55. Uddin J, Zwisler AD, Lewinter C, Moniruzzaman M, Lund K, Tang LH, et al. Predictors of exercise capacity following exercise-based rehabilitation in patients with coronary heart disease and heart failure: A meta-regression analysis. European journal of preventive cardiology. 2016;23(7):683-93.

56. Alvarez P, Hannawi B, Guha A. Exercise And Heart Failure: Advancing Knowledge And Improving Care. Methodist Debakey Cardiovasc J. 2016;12(2):110-5.

57. Keteyian SJ, Patel M, Kraus WE, Brawner CA, McConnell TR, Piña IL, et al. Variables Measured During Cardiopulmonary Exercise Testing as Predictors of Mortality in Chronic Systolic Heart Failure. J Am Coll Cardiol. 2016;67(7):780-9.

58. Ostman C, Jewiss D, Smart NA. The Effect of Exercise Training Intensity on Quality of Life in Heart Failure Patients: A Systematic Review and Meta-Analysis. Cardiology. 2017;136(2):79-89.

59. La Rovere MT, Traversi E. Role and efficacy of cardiac rehabilitation in patients with heart failure. Monaldi Arch Chest Dis. 2019;89(1).

6o. Papathanasiou JV, Petrov I, Tokmakova MP, Dimitrova DD, Spasov L, Dzhafer NS, et al. Group-based cardiac rehabilitation interventions. A challenge for physical and rehabilitation medicine physicians: a randomized controlled trial. Eur J Phys Rehabil Med. 2020.

61. Taylor RS, Sagar VA, Davies EJ, Briscoe S, Coats AJ, Dalal H, et al. Exercise-based rehabilitation for heart failure. Cochrane Database Syst Rev. 2014(4):Cdoo3331.

62. Corrà U, Giannuzzi P, Adamopoulos S, Bjornstad H, BjarnasonWeherns B, Cohen-Solal A, et al. Executive summary of the position paper of the Working Group on Cardiac Rehabilitation and Exercise Physiology of the European Society of Cardiology (ESC): core components of cardiac rehabilitation in chronic heart failure. Eur $\mathrm{J}$ Cardiovasc Prev Rehabil. 2005;12(4):321-5.

63. Piepoli MF, Corrà U, Adamopoulos S, Benzer W, Bjarnason-Wehrens $\mathrm{B}$, Cupples M, et al. Secondary prevention in the clinical management of patients with cardiovascular diseases. Core components, standards and outcome measures for referral and delivery: a policy statement from the cardiac rehabilitation section of the European Association for Cardiovascular Prevention \& Rehabilitation. Endorsed by the Committee for Practice Guidelines of the European Society of Cardiology. European journal of preventive cardiology. 2014;21(6):664-81.

64. Burnet K, Kelsch E, Zieff G, Moore JB, Stoner L. How fitting is F.I.T.T.?: A perspective on a transition from the sole use of frequency, intensity, time, and type in exercise prescription. Physiol Behav. 2019;199:33-4.

65. Karimi M, Brazier J. Health, Health-Related Quality of Life, and Quality of Life: What is the Difference? Pharmacoeconomics. 2016;34(7):645-9. 
66. Zuluaga MC, Guallar-Castillon P, Lopez-Garcia E, Banegas JR, CondeHerrera M, Olcoz-Chiva M, et al. Generic and disease-specific quality of life as a predictor of long-term mortality in heart failure. Eur J Heart Fail. 2010;12(12):1372-8.

67. Juenger J, Schellberg D, Kraemer S, Haunstetter A, Zugck C, Herzog $\mathrm{W}$, et al. Health related quality of life in patients with congestive heart failure: comparison with other chronic diseases and relation to functional variables. Heart. 2002;87(3):235-41.

68. Alonso J, Ferrer M, Gandek B, Ware JE, Jr., Aaronson NK, Mosconi P, et al. Health-related quality of life associated with chronic conditions in eight countries: results from the International Quality of Life Assessment (IQOLA) Project. Qual Life Res. 2004;13(2):283-98.

69. van Tol BA, Huijsmans RJ, Kroon DW, Schothorst M, Kwakkel G. Effects of exercise training on cardiac performance, exercise capacity and quality of life in patients with heart failure: a meta-analysis. Eur $\mathbf{J}$ Heart Fail. 2006;8(8):841-50.

70. WHO. Adherence to long term therapies-evidence for action. Geneva, World Health Organization 2003. Retrieved from WHO website: http://www.who.int/chp/knowledge/publications/adherence report /en

71. Conraads VM, Deaton C, Piotrowicz E, Santaularia N, Tierney S, Piepoli MF, et al. Adherence of heart failure patients to exercise: barriers and possible solutions: a position statement of the Study Group on Exercise Training in Heart Failure of the Heart Failure Association of the European Society of Cardiology. Eur J Heart Fail. 2012;14(5):451-8.

72. Palmer K, Bowles KA, Lane R, Morphet J. Barriers to Engagement in Chronic Heart Failure Rehabilitation: An Australian Survey. Heart Lung Circ. 2020;29(8):e177-e84.

73. ATS statement: guidelines for the six-minute walk test. Am J Respir Crit Care Med. 2002;166(1):111-7.

74. Borg G. Borg's Perceived exertion and pain scales. Champaign, Ill.: Human Kinetics; 1998.

75. Brudin L, Jorfeldt L, Pahlm O. Comparison of two commonly used reference materials for exercise bicycle tests with a Swedish clinical database of patients with normal outcome. Clin Physiol Funct Imaging. 2014;34(4):297-307.

76. Brauer K, Jorfeldt L, Pahlm O. Det kliniska arbetsprovet: Studentlitteratur; 2003.

77. Franzen K, Blomqvist K, Saveman BI. Impact of chronic heart failure on elderly persons' daily life: a validation study. Eur J Cardiovasc Nurs. 2006;5(2):137-45.

78. Sullivan M, Karlsson J, Ware JE, Jr. The Swedish SF-36 Health Survey-I. Evaluation of data quality, scaling assumptions, reliability and construct validity across general populations in Sweden. Soc Sci Med. 1995;41(10):1349-58. 
79. Sullivan M, Karlsson J, Ware J. SF-36 hälsoenkät: svensk manual och tolkningsguide $=($ Swedish manual and interpretation guide). Gothenburg: Sahlgrenska University Hospital. 1994.

80. Ware JE, Jr., Sherbourne CD. The MOS 36-item short-form health survey (SF-36). I. Conceptual framework and item selection. Med Care. 1992;30(6):473-83.

81. Rector TS, Cohn JN. Assessment of patient outcome with the Minnesota Living with Heart Failure questionnaire: reliability and validity during a randomized, double-blind, placebo-controlled trial of pimobendan. Pimobendan Multicenter Research Group. Am Heart J. 1992;124(4):1017-25.

82. Rector TS, Kubo SH, Cohn JN. Validity of the Minnesota Living with Heart Failure questionnaire as a measure of therapeutic response to enalapril or placebo. Am J Cardiol. 1993;71(12):1106-7.

83. Riegel B, Moser DK, Glaser D, Carlson B, Deaton C, Armola R, et al. The Minnesota Living With Heart Failure Questionnaire: sensitivity to differences and responsiveness to intervention intensity in a clinical population. Nurs Res. 2002;51(4):209-18.

84. Willenheimer R, Erhardt L, Cline C, Rydberg E, Israelsson B. Exercise training in heart failure improves quality of life and exercise capacity. Eur Heart J. 1998;19(5):774-81.

85. Björk J. Praktisk statistik för medicin och hälsa: Liber; 2011.

86. Kirkwood BR, Sterne JA. Essentials of medical statistics. 2nd edition ed: Oxford : Blackwell; 2000.

87. Bland JM, Altman DG. Statistical methods for assessing agreement between two methods of clinical measurement. Lancet. 1986;1(8476):307-10.

88. Dahlberg G. Statistical methods for medical and biological students. London: George Allen and Unwin; 1940. 122-32 p.

89. O'Keeffe ST, Lye M, Donnellan C, Carmichael DN. Reproducibility and responsiveness of quality of life assessment and six minute walk test in elderly heart failure patients. Heart. 1998;80(4):377-82.

90. Demers C, McKelvie RS, Negassa A, Yusuf S. Reliability, validity, and responsiveness of the six-minute walk test in patients with heart failure. Am Heart J. 2001;142(4):698-703.

91. Enright PL, Sherrill DL. Reference equations for the six-minute walk in healthy adults. Am J Respir Crit Care Med. 1998;158(5 Pt 1):1384-7.

92. Sullivan M, Higginbotham M, Cobb F. Exercise training in patients with severe left ventricular dysfunction. Hemodynamic and metabolic effects. Circulation. 1988;78(3):506-15.

93. McConnell TR. A review to develop an effective exercise training for heart failure patients. Eura Medicophys. 2005;41(1):49-56.

94. Chien CL, Lee CM, Wu YW, Chen TA, Wu YT. Home-based exercise increases exercise capacity but not quality of life in people with chronic heart failure: a systematic review. Aust J Physiother. 2008;54(2):8793 . 
95. Safiyari-Hafizi H, Taunton J, Ignaszewski A, Warburton DE. The Health Benefits of a 12-Week Home-Based Interval Training Cardiac Rehabilitation Program in Patients With Heart Failure. Can J Cardiol. 2016;32(4):561-7.

96. Munch GW, Rosenmeier JB, Petersen M, Rinnov AR, Iepsen UW, Pedersen BK, et al. Comparative Effectiveness of Low-Volume TimeEfficient Resistance Training Versus Endurance Training in Patients With Heart Failure. J Cardiopulm Rehabil Prev. 2018;38(3):175-81.

97. Tyni-Lenne R, Dencker K, Gordon A, Jansson E, Sylven C. Comprehensive local muscle training increases aerobic working capacity and quality of life and decreases neurohormonal activation in patients with chronic heart failure. Eur J Heart Fail. 2001;3(1):47-52.

98. Pu CT, Johnson MT, Forman DE, Hausdorff JM, Roubenoff R, Foldvari $\mathrm{M}$, et al. Randomized trial of progressive resistance training to counteract the myopathy of chronic heart failure. Journal of applied physiology (Bethesda, Md : 1985). 2001;90(6):2341-50.

99. Doherty P, Harrison AS, Hossain R. Determinants of walking fitness in patients with heart failure attending cardiac rehabilitation. Open heart. 2019;6(1):e00o866.

100. Brubaker PH, Moore JB, Stewart KP, Wesley DJ, Kitzman DW. Endurance exercise training in older patients with heart failure: results from a randomized, controlled, single-blind trial. J Am Geriatr Soc. 2009;57(11):1982-9.

101. Witham MD, Fulton RL, Greig CA, Johnston DW, Lang CC, van der Pol M, et al. Efficacy and cost of an exercise program for functionally impaired older patients with heart failure: a randomized controlled trial. Circ Heart Fail. 2012;5(2):209-16.

102. Pickering C, Kiely J. Do Non-Responders to Exercise Exist-and If So, What Should We Do About Them? Sports Med. 2019;49(1):1-7.

103. Corrà U, Piepoli MF, Adamopoulos S, Agostoni P, Coats AJ, Conraads $\mathrm{V}$, et al. Cardiopulmonary exercise testing in systolic heart failure in 2014: the evolving prognostic role: a position paper from the committee on exercise physiology and training of the heart failure association of the ESC. Eur J Heart Fail. 2014;16(9):929-41.

104. Malhotra R, Bakken K, D'Elia E, Lewis GD. Cardiopulmonary Exercise Testing in Heart Failure. JACC Heart failure. 2016;4(8):607-16.

105. Arena R, Myers J, Guazzi M. Cardiopulmonary exercise testing is a core assessment for patients with heart failure. Congest Heart Fail. 2011;17(3):115-9.

106. Ingle L, Cleland JG, Clark AL. The long-term prognostic significance of 6-minute walk test distance in patients with chronic heart failure. Biomed Res Int. 2014;2014:505969.

107. Du H, Wonggom P, Tongpeth J, Clark RA. Six-Minute Walk Test for Assessing Physical Functional Capacity in Chronic Heart Failure. Curr Heart Fail Rep. 2017;14(3):158-66. 
108. Cornelis J, Beckers P, Taeymans J, Vrints C, Vissers D. Comparing exercise training modalities in heart failure: A systematic review and meta-analysis. Int J Cardiol. 2016;221:867-76.

109. Cahalin LP, Mathier MA, Semigran MJ, Dec GW, DiSalvo TG. The sixminute walk test predicts peak oxygen uptake and survival in patients with advanced heart failure. Chest. 1996;110(2):325-32.

110. Ross RM, Murthy JN, Wollak ID, Jackson AS. The six minute walk test accurately estimates mean peak oxygen uptake. BMC Pulm Med. 2010;10:31.

111. Wu G, Sanderson B, Bittner V. The 6-minute walk test: how important is the learning effect? Am Heart J. 2003;146(1):129-33.

112. Guyatt GH, Sullivan MJ, Thompson PJ, Fallen EL, Pugsley SO, Taylor DW, et al. The 6-minute walk: a new measure of exercise capacity in patients with chronic heart failure. Can Med Assoc J. 1985;132(8):91923.

113. Hamilton DM, Haennel RG. Validity and reliability of the 6-minute walk test in a cardiac rehabilitation population. J Cardiopulm Rehabil. 2000;20(3):156-64.

114. Singh SJ, Puhan MA, Andrianopoulos V, Hernandes NA, Mitchell KE, Hill CJ, et al. An official systematic review of the European Respiratory Society/American Thoracic Society: measurement properties of field walking tests in chronic respiratory disease. Eur Respir J. 2014;44(6):1447-78.

115. Lainchbury JG, Richards AM. Exercise testing in the assessment of chronic congestive heart failure. Heart. 2002;88(5):538-43.

116. Holland AE, Spruit MA, Troosters T, Puhan MA, Pepin V, Saey D, et al. An official European Respiratory Society/American Thoracic Society technical standard: field walking tests in chronic respiratory disease. Eur Respir J. 2014;44(6):1428-46.

117. Guyatt GH, Pugsley SO, Sullivan MJ, Thompson PJ, Berman L, Jones $\mathrm{NL}$, et al. Effect of encouragement on walking test performance. Thorax. 1984;39(11):818-22.

118. Barbour KA, Miller NH. Adherence to exercise training in heart failure: a review. Heart Fail Rev. 2008;13(1):81-9.

119. Duncan KA, Pozehl B. Staying on course: the effects of an adherence facilitation intervention on home exercise participation. Prog Cardiovasc Nurs. 2002;17(2):59-65, 71.

120. Buckingham SA, Taylor RS, Jolly K, Zawada A, Dean SG, Cowie A, et al. Home-based versus centre-based cardiac rehabilitation: abridged Cochrane systematic review and meta-analysis. Open heart. 2016;3(2):e000463.

121. Tang LH, Kikkenborg Berg S, Christensen J, Lawaetz J, Doherty P, Taylor RS, et al. Patients' preference for exercise setting and its influence on the health benefits gained from exercise-based cardiac rehabilitation. Int J Cardiol. 2017;232:33-9. 
122. Dracup K, Evangelista LS, Hamilton MA, Erickson V, Hage A, Moriguchi J, et al. Effects of a home-based exercise program on clinical outcomes in heart failure. Am Heart J. 2007;154(5):877-83.

123. Oka RK, De Marco T, Haskell WL, Botvinick E, Dae MW, Bolen K, et al. Impact of a home-based walking and resistance training program on quality of life in patients with heart failure. Am $\mathrm{J}$ Cardiol. 2000;85(3):365-9.

124. Oka RK, DeMarco T, Haskell WL. Effect of treadmill testing and exercise training on self-efficacy in patients with heart failure. Eur $\mathrm{J}$ Cardiovasc Nurs. 2005;4(3):215-9.

125. Rajati F, Sadeghi M, Feizi A, Sharifirad G, Hasandokht T, Mostafavi F. Self-efficacy strategies to improve exercise in patients with heart failure: A systematic review. ARYA atherosclerosis. 2014;10(6):319-33.

126. Toukhsati SR, Mathews S, Sheed A, Freijah I, Moncur L, Cropper P, et al. Confirming a beneficial effect of the six-minute walk test on exercise confidence in patients with heart failure. Eur $\mathrm{J}$ Cardiovasc Nurs. 2020;19(2):165-71.

127. Hambrecht R, Fiehn E, Yu J, Niebauer J, Weigl C, Hilbrich L, et al. Effects of endurance training on mitochondrial ultrastructure and fiber type distribution in skeletal muscle of patients with stable chronic heart failure. J Am Coll Cardiol. 1997;29(5):1067-73.

128. Meyer K, Samek L, Schwaibold M, Westbrook S, Hajric R, Beneke R, et al. Interval training in patients with severe chronic heart failure: analysis and recommendations for exercise procedures. Med Sci Sports Exerc. 1997;29(3):306-12.

129. Tyni-Lenne R, Gordon A, Europe E, Jansson E, Sylven C. Exercisebased rehabilitation improves skeletal muscle capacity, exercise tolerance, and quality of life in both women and men with chronic heart failure. J Card Fail. 1998;4(1):9-17.

130. Wielenga RP, Huisveld IA, Bol E, Dunselman PH, Erdman RA, Baselier MR, et al. Safety and effects of physical training in chronic heart failure. Results of the Chronic Heart Failure and Graded Exercise study (CHANGE). Eur Heart J. 1999;20(12):872-9.

131. Hwang R, Marwick T. Efficacy of home-based exercise programmes for people with chronic heart failure: a meta-analysis. Eur J Cardiovasc Prev Rehabil. 2009;16(5):527-35.

132. Willenheimer R, Rydberg E, Cline C, Broms K, Hillberger B, Oberg L, et al. Effects on quality of life, symptoms and daily activity 6 months after termination of an exercise training programme in heart failure patients. Int J Cardiol. 2001;77(1):25-31.

133. Belardinelli R, Georgiou D, Cianci G, Purcaro A. Randomized, controlled trial of long-term moderate exercise training in chronic heart failure: effects on functional capacity, quality of life, and clinical outcome. Circulation. 1999;99(9):1173-82.

134. Kavanagh T, Myers MG, Baigrie RS, Mertens DJ, Sawyer P, Shephard RJ. Quality of life and cardiorespiratory function in chronic heart failure: effects of 12 months' aerobic training. Heart. 1996;76(1):42-9. 
135. McKelvie RS, Teo KK, Roberts R, McCartney N, Humen D, Montague $\mathrm{T}$, et al. Effects of exercise training in patients with heart failure: the Exercise Rehabilitation Trial (EXERT). Am Heart J. 2002;144(1):2330.

136. Corvera-Tindel T, Doering LV, Woo MA, Khan S, Dracup K. Effects of a home walking exercise program on functional status and symptoms in heart failure. Am Heart J. 2004;147(2):339-46.

137. Evangelista LS, Doering LV, Lennie T, Moser DK, Hamilton MA, Fonarow GC, et al. Usefulness of a home-based exercise program for overweight and obese patients with advanced heart failure. Am J Cardiol. 2006;97(6):886-90.

138. de Mello Franco FG, Santos AC, Rondon MU, Trombetta IC, Strunz C, Braga AM, et al. Effects of home-based exercise training on neurovascular control in patients with heart failure. Eur J Heart Fail. 2006;8(8):851-5.

139. Witham MD, Gray JM, Argo IS, Johnston DW, Struthers AD, McMurdo ME. Effect of a seated exercise program to improve physical function and health status in frail patients $>$ or $=70$ years of age with heart failure. Am J Cardiol. 2005;95(9):1120-4.

140. Taylor RS, Dalal H, Jolly K, Zawada A, Dean SG, Cowie A, et al. Homebased versus centre-based cardiac rehabilitation. Cochrane Database Syst Rev. 2015(8):CDo07130.

141. Belardinelli R, Georgiou D, Cianci G, Purcaro A. 10-year exercise training in chronic heart failure: a randomized controlled trial. $\mathrm{J} \mathrm{Am}$ Coll Cardiol. 2012;60(16):1521-8.

142. O'Connor CM, Whellan DJ, Lee KL, Keteyian SJ, Cooper LS, Ellis SJ, et al. Efficacy and safety of exercise training in patients with chronic heart failure: HF-ACTION randomized controlled trial. JAMA. 2009;301(14):1439-50.

143. Wisløff U, Støylen A, Loennechen JP, Bruvold M, Rognmo Ø, Haram PM, et al. Superior cardiovascular effect of aerobic interval training versus moderate continuous training in heart failure patients: a randomized study. Circulation. 2007;115(24):3086-94.

144. Shah M, Bhalla V, Patnaik S, Maludum O, Lu M, Figueredo VM. Heart failure and the holidays. Clin Res Cardiol. 2016;105(10):865-72.

145. Klompstra L, Jaarsma T, Strömberg A, van der Wal MHL. Seasonal variation in physical activity in patients with heart failure. Heart Lung. 2019;48(5):381-5. 



\section{Papers}

The papers associated with this thesis have been removed for copyright reasons. For more details about these see:

http://urn.kb.se/resolve?urn=urn:nbn:se:liu:diva-171921 


\section{FACULTY OF MEDICINE AND HEALTH SCIENCES}

Linköping University Medical Dissertations No. 1766, 2021

Department of Health Medicine and Caring Sciences

Linköping University

SE-581 83 Linköping, Sweden

www.liu.se 